\title{
Oceanography
}

CITATION

Gledhill, D.K., M.M. White, J. Salisbury, H. Thomas, I. Mlsna, M. Liebman, B. Mook, J. Grear, A.C. Candelmo, R.C. Chambers, C.J. Gobler, C.W. Hunt, A.L. King, N.N. Price, S.R. Signorini, E. Stancioff, C. Stymiest, R.A. Wahle, J.D. Waller, N.D. Rebuck, Z.A. Wang, T.L. Capson, J.R. Morrison, S.R. Cooley, and S.C. Doney. 2015. Ocean and coastal acidification off New England and Nova Scotia. Oceanography 28(2):182-197, http://dx.doi.org/10.5670/oceanog.2015.41.

DOI

http://dx.doi.org/10.5670/oceanog.2015.41

COPYRIGHT

This article has been published in Oceanography, Volume 28, Number 2, a quarterly journal of The Oceanography Society. Copyright 2015 by The Oceanography Society. All rights reserved.

USAGE

Permission is granted to copy this article for use in teaching and research. Republication, systematic reproduction, or collective redistribution of any portion of this article by photocopy machine, reposting, or other means is permitted only with the approval of The Oceanography Society. Send all correspondence to: info@tos.org or The Oceanography Society, PO Box 1931, Rockville, MD 20849-1931, USA. 


\section{Ocean and Coastal Acidification off New England and Nova Scotia}

By Dwight K. Gledhill, Meredith M. White, Joseph Salisbury, Helmuth Thomas, Ivy Mlsna,

Matthew Liebman, Bill Mook, Jason Grear, Allison C. Candelmo, R. Christopher Chambers,

Christopher J. Gobler, Christopher W. Hunt, Andrew L. King, Nichole N. Price, Sergio R. Signorini,

Esperanza Stancioff, Cassie Stymiest, Richard A. Wahle, Jesica D. Waller, Nathan D. Rebuck,

Zhaohui A. Wang, Todd L. Capson, J. Ruairidh Morrison, Sarah R. Cooley, and Scott C. Doney

ABSTRACT. New England coastal and adjacent Nova Scotia shelf waters have a reduced buffering capacity because of significant freshwater input, making the region's waters potentially more vulnerable to coastal acidification. Nutrient loading and heavy precipitation events further acidify the region's poorly buffered coastal waters. Despite the apparent vulnerability of these waters, and fisheries' and mariculture's significant dependence on calcifying species, the community lacks the ability to confidently predict how the region's ecosystems will respond to continued ocean and coastal acidification. Here, we discuss ocean and coastal acidification processes specific to New England coastal and Nova Scotia shelf waters and review current understanding of the biological consequences most relevant to the region. We also identify " key research and monitoring needs to be addressed and highlight existing capacities that should be leveraged to advance a regional understanding of ocean and coastal acidification.
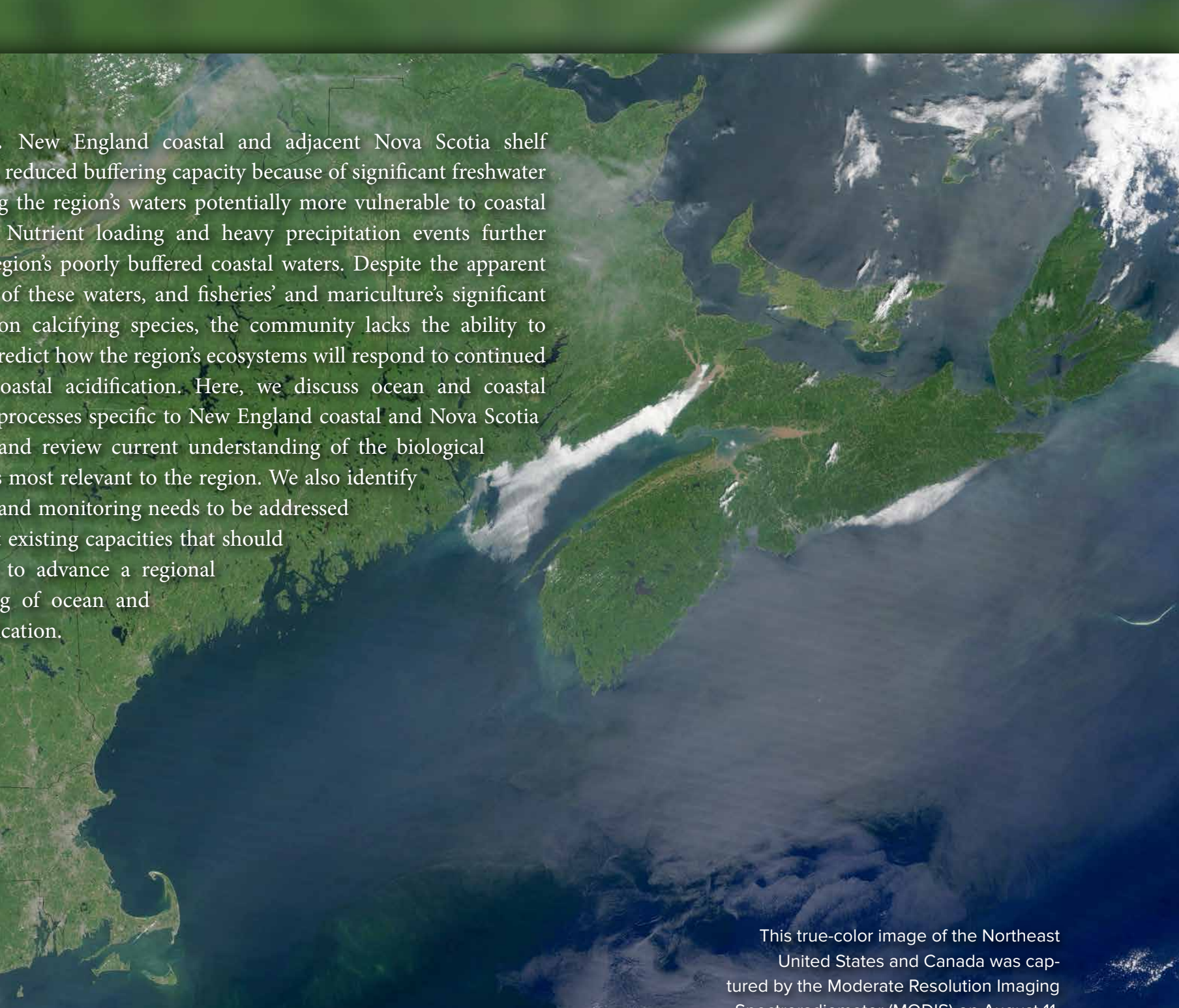

This true-color image of the Northeast United States and Canada was captured by the Moderate Resolution Imaging Spectroradiometer (MODIS) on August 11, 2002. Credit: Jacques Descloitres, MODIS Rapid Response Team, NASA GSFC 


\section{INTRODUCTION}

Long-term, sustained time-series stations and repeated geochemical surveys both show that the global ocean is acidifying concurrent with rising atmospheric $\mathrm{CO}_{2}$ (Takahashi et al., 2014) at rates likely unprecedented in Earth history (Zeebe, 2012). Chemical changes in seawater as a result of the uptake of $\mathrm{CO}_{2}$ include increasing concentrations of dissolved inorganic carbon (DIC), the production of carbonic acid (lowering of $\mathrm{pH}$ ), an increase in the partial pressure of seawater $\mathrm{CO}_{2, \mathrm{sw}}\left(p \mathrm{CO}_{2, \mathrm{sw}}\right)$, and a decrease in the availability of carbonate ion. How these changes will affect marine life is a prominent issue for contemporary oceanography. Early studies explored the effects on marine calcifiers and generally demonstrated negative impacts to biocalcification. These findings raised concerns about living marine resources and their dependent human communities. In subsequent years, species response studies have explored an ever-increasing array of marine taxa from phytoplankton to fish, revealing a diverse spectrum of taxaspecific responses beyond biocalcification (Orr et al., 2005; Doney et al., 2009). Still, much uncertainty remains regarding the biological effects of ocean acidification (OA) and how it will interact with other global aspects of a changing ocean. Many species and life stages most sensitive to OA (e.g., shellfish larvae) reside within biogeochemically complex coastal waters that can exhibit enhanced "coastal acidification" (Strong et al., 2014; Wallace et al., 2014). These two forms of acidification, ocean and coastal acidification (OCA), can be roughly described and compared as follows.

Ocean Acidification. Ocean acidification changes the carbonate chemistry of seawater in response to large-scale physical oceanic processes that include the global uptake of atmospheric $\mathrm{CO}_{2}$ as well as the entrainment of acidified subsurface waters due to vertical mixing and upwelling. Waters of the Scotian Shelf, western
Gulf of Maine (GOM), central GOM, Georges Bank and Nantucket Shoals, and the northern Middle Atlantic Bight (MAB) likely represent systems within the Northeast Coastal Acidification Network (NECAN) study area where ocean acidification will be more readily discernible than could be the case for the complex nearshore environments. The rate of ocean acidification of these waters is similar to the rate of atmospheric $\mathrm{CO}_{2}$ increase further modified by the effects of multidecadal oscillation (e.g., the Atlantic multidecadal oscillation) processes

Coastal Acidification. The supply of varying amounts of DIC, dissolved and particulate organic carbon, and nutrients from riverine and estuarine sources, as well as total alkalinity (TA), can all significantly affect the local carbonate chemistry of the receiving water mass. Some coastal waters in the New England/ Nova Scotia region are influenced by nutrient loading and significant freshwater inputs that can episodically yield riverine plumes corrosive to calcium carbonate (i.e., conditions where dissolution is favored). Nutrient loading promotes organic matter production by autotrophy, which can later result in intense respiration by heterotrophs that drives up local $\mathrm{CO}_{2}$ concentrations. Coastal acidification generally exhibits higher frequency variability relative to ocean acidification (except in cases of episodic upwelling), resulting in short-term episodic events.

From an organism's perspective, there is little distinction in the resulting chemistry between the two forms of acidification (Waldbusser and Salisbury, 2014). However, the frequency dynamics of the two processes are very different and will be described further in the following sections.

OCA effects are evident along all coastal margins (see McLaughlin et al., 2015, in this issue), including the US West Coast where upwelling episodically supplies waters corrosive to oyster larvae (see
Barton et al., 2015, in this issue). High levels of larval mortalities were attributed to such events beginning in 2007 at two key Pacific Northwest shellfish hatcheries. This event garnered considerable attention worldwide from coastal communities concerned that this situation may be a harbinger of things to come elsewhere. New England and Scotian Shelf waters may be at elevated risk for OCA due to the reduced buffering capacity of these coastal waters relative to more southern US coastal waters (Wang et al., 2013). A well-buffered solution's $\mathrm{pH}$ changes very little when an acid is added. In the case of OCA, carbonic acid is generated when $\mathrm{CO}_{2}$ is added to the water (either from the atmosphere or due to respiration). The capacity of seawater to resist the addition of this acid is termed "buffering capacity." Hence, seawater with reduced buffering capacity exhibits a more pronounced $\mathrm{pH}$ change for a given input of $\mathrm{CO}_{2}$, making episodic excursions to corrosive conditions more likely. Buffering capacity is lowered in the Northeast waters primarily as a result of (1) the effect lower temperatures have on the carbonic acid system and (2) changes in the concentration of TA and DIC or their ratios by dilution with freshwater or the addition/ consumption of DIC by biology.

Because many communities in this region are socioeconomically and culturally dependent on commercial and recreational fishing, it is important to carefully investigate the implications of OCA. This paper reviews the science specific to acidification of coastal waters (nearshore out to the shelf break) extending from Long Island Sound (LIS) to the Canadian Scotian Shelf. NECAN facilitated the review, which includes input from dozens of scientists and stakeholders engaged in advancing our understanding of OCA within the New England/Nova Scotia region. The content was derived largely from a subject matter expert webinar series (http://www.neracoos.org/necan) followed by a two-day workshop held in New Hampshire in April 2014. 


\section{THE NORTHEAST COASTAL ACIDIFICATION NETWORK}

NECAN's geographic focus encompasses the waters from LIS, Georges Bank, the GOM and Browns Bank, and Sable Island Bank out to the shelf break. This New England/Nova Scotia region represents some of the most valuable marine resource real estate in the world, providing direct economic benefit to at least six US states (New York, Connecticut, Rhode Island, Massachusetts, New Hampshire, and Maine) and two Canadian provinces (Nova Scotia and New Brunswick). The New England fishing industry is deeply rooted in the region's culture, having been established as the first colonial industry in America over 400 years ago. Fishery impacts to coastal ecosystems have escalated over time, and with the depletion of large predatory groundfish in the 1950s (Bourque et al., 2007), catch has increasingly transitioned to prey species, such as lobster (Steneck et al., 2011). In 2012, New England landed 301,185 metric tons of finfish and shellfish, earning $\$ 1.2$ billion in landings revenue (NMFS, 2014). Two-thirds of these landings can be attributed to American lobster and sea scallop (Figure 1), two species that are heavily dependent upon biocalcification processes. In 2013, mollusks represented $41.5 \%$ of fisheries landings values in New England, with a total value greater than $\$ 482$ million (NMFS, 2014) and ecosystem services far exceeding that value (Costanza et al., 1997). The MAB shelf break is also a highproduction area and an important commercial fishing ground, including intensive lobster fishing activities. The dependence of commercial fisheries on calcifying species sets the New England/Nova Scotia region apart from other coastal regions of the United States. Of the key species harvested in the New England/Nova Scotia region (Figure 1), few have been investigated in terms of their sensitivity to changes in carbonate chemistry, and of those that have, limited life stages have been tested (see later discussion).

NECAN aims to foster regional engagement on OCA, improve understanding of what OCA means to regional stakeholders, and connect a broad range of interest groups. Industries and business groups that could potentially be impacted

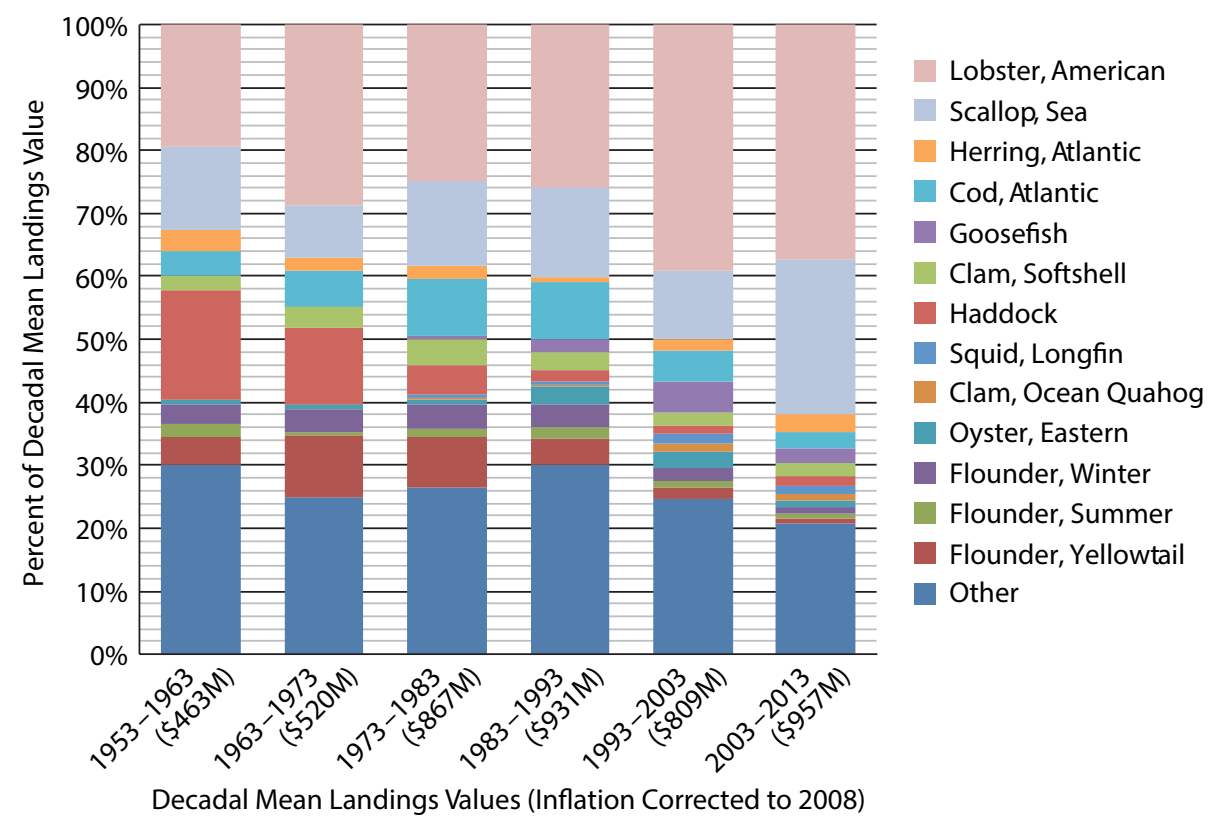

FIGURE 1. New England fisheries species decadal commercial landing statistics as reported from the National Oceanic Atmospheric Administration National Marine Fisheries Service (2014; http://www.st.nmfs.noaa.gov) and inflation corrected to 2008 (http://www.bls.gov). Note the growing importance of American lobster and sea scallop in terms of total landed value by ocean (long-term) and coastal (nearterm) acidification include aquaculture, wild harvesters of both fish and shellfish, wholesalers, seafood distributors, restaurants, and markets. These groups need objective information on OCA, and the scientific community needs their input to design effective monitoring and research strategies for the region. In April 2014, Maine established the Commission to Study the Effects of Coastal and Ocean Acidification and its Existing and Potential Effects on Species that are Commercially Harvested and Grown Along the Maine Coast. Comprised of two subcommittees, one that reviewed Washington State's OA Commission Report and another that reviewed the state of the science (partly informed through NECAN), the commission issued a report in December 2014 to the Maine legislature that provided recommendations for monitoring and research relevant to Maine. The Commission's make-up included: two members of the Maine Senate, three members of the Maine House of Representatives, eight members appointed by the Commissioner of Marine Resources (including a representative of an environmental/ community group, several persons who fish commercially, and ocean acidification scientists), and designees of the Commissioner of Marine Resources, Commissioner of Environmental Protection, and the Commissioner of Agriculture, Conservation, and Forestry. Recommendations included establishing a Maine OA Commission to offer continued policy recommendations to the state legislature.

\section{OCEAN AND COASTAL ACIDIFICATION OF THE NEW ENGLAND/ NOVA SCOTIA REGION}

A range of marine organisms that includes shellfish, corals, and pteropods is generally thought to be sensitive to changes in the degree to which waters are supersaturated with respect to calcium carbonate, the building block for 
their shells and skeletons (Doney et al. 2009). This degree of saturation is commonly expressed relative to the mineral aragonite (or calcite), the most common marine form of calcium carbonate, and is denoted as $\Omega_{\text {arag }}\left(\right.$ or $\Omega_{\text {cal }}$ ). An $\Omega_{\text {arag }}$ value $>1.0$ indicates supersaturation, while values $<1.0$ indicate undersaturationconditions corrosive to aragonite. Generally, the more seawater is saturated with calcium carbonate, the faster the rate of mineral precipitation (Morse et al., 2007) and the less energy it takes to produce a shell (e.g., Waldbusser et al., 2015). Most marine calcifiers require $\Omega_{\text {arag }}$ well in excess of 1.0 to optimally produce skeletons (see later discussion). As a result of OCA, seawater becomes less saturated ( $\Omega_{\text {arag }}$ decreases) with increasing $p \mathrm{CO}_{2}$, thereby requiring organisms to expend additional energy for shell production. Furthermore, $\Omega_{\text {arag }}$ values can also be depressed (even to corrosive levels) at colder temperatures or by dilution with freshwater. Debate continues within the scientific community with respect to designating critical "thresholds" of $\Omega_{\text {arag }}$ for different species. Is it a thermodynamic or kinetic threshold for mineral precipitation? Or, is it the point at which the rate of chemical change exceeds a species' adaptive capacity (Friedrich et al., 2012)? Alternatively, thresholds could be defined as the point at which ambient chemistry conditions permanently exceed the pre-industrial range of natural variability (e.g., Ekstrom et al., 2015). Indeed, careful consideration needs to be given to how we define acidification thresholds for the question at hand.

In an effort to map potentially vulnerable zones within the New England/ Nova Scotia region, we use a gridded data product (see online Supplemental Methods) to estimate $\Omega_{\text {arag }}$ through the coupling of surface $\mathrm{CO}_{2}$ partial pressure $\left(p \mathrm{CO}_{2, \mathrm{sw}}\right)$, according to Signorini et al. (2013), to total alkalinity derived from TA-salinity relationships obtained from historical ship surveys in a similar manner adopted previously to map OA dynamics (e.g., Gledhill et al., 2008,
2009). This approach could not be applied to LIS primarily because of satellite land masking, but it does capture the seasonal dynamics across much of the remaining region. Provided the thermodynamic threshold $\left(\Omega_{\text {arag }}=1\right)$ represents perhaps a more conservative benchmark of concern for marine life, we have elected to map minimum monthly mean $\Omega_{\text {arag values }}$ across the region (Figure 2). Regionally, the lowest values tend to occur in early spring, particularly along the Scotian Shelf. During this period, monthly mean $\Omega_{\text {arag }}$ values north of Cape Cod are generally between $\sim 1.2$ and 1.5 (or frequently lower), levels where acute responses of bivalve larvae have been observed (Waldbusser et al., 2015).

An important factor contributing to the regionally depressed $\Omega_{\text {arag }}$ values in the New England/Nova Scotia region is freshwater input (rivers, snow melt, ice melt). The entire region exhibits much lower surface salinities relative to typical North Atlantic oceanic waters due in large part to the Labrador Current (Figure 3). The Labrador Current is heavily influenced by Arctic water outflow and the St. Lawrence River, which as the outflow of the Great Lakes, is one of the largest in North America. The current flows along the Scotian Shelf into the GOM, supplying poorly buffered waters to the Bay of Fundy and the Maine Coastal Current. This low-salinity water exhibits reduced concentrations of both carbonate and the calcium ions, which directly determine $\Omega_{\text {arag }}$. In addition, Figure 2 reveals several locations within the region that are actually corrosive $\left(\Omega_{\mathrm{arag}}<1\right)$. These areas generally occur where coastal acidification processes dominate, such as the Penobscot and Kennebec River mouths, and within bays such as Boston Harbor or Cape Cod Bay.

Using this model, we also explored the primary controls on the seasonal dynamics from selected locations throughout the region, except for the LIS, where we instead estimate seasonal dynamics from monthly composited US Environmental Protection Agency $\mathrm{pH}$ data collected there from 2010 through 2013 (see online Supplemental Methods). Figure 4 illustrates the resulting $\Omega_{\text {arag }}$ dynamics from the combined effects of cool temperature, freshwater (Salisbury et al., 2008, 2009), and biological productivity/respiration at each of the selected locations. Locations denoted in Figure 4 as "OA" are where atmospheric uptake of $\mathrm{CO}_{2}$ and largescale oceanic processes are important drivers of long-term changes in $\Omega_{\text {arag, }}$, while those labeled "CA" are locations where coastal acidification processes are important and can result in episodic corrosive conditions as described previously.

In all cases, the time-series plots in Figure 4 show that the dynamic range in $\Omega_{\text {arag }}$ at seasonal (or episodic) time scales can exceed a full unit, considerably greater than the anticipated annual

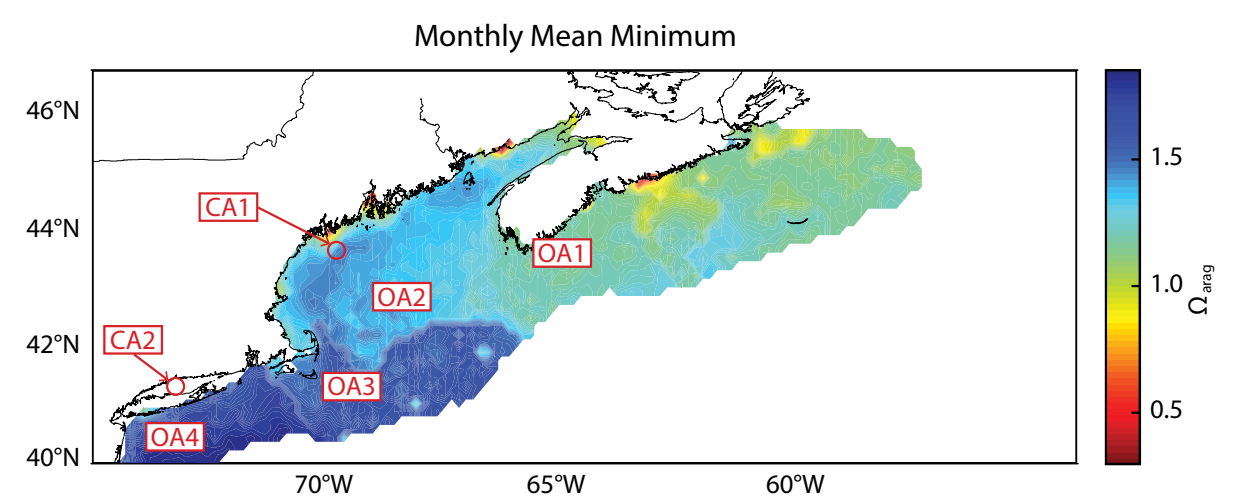

FIGURE 2. Mapped distribution of minimum monthly averaged sea surface aragonite saturation state $\left(\Omega_{\text {arag }}\right)$ for the Northeast Coastal Acidification Network (NECAN) study region based upon a coupling of the surface $p \mathrm{CO}_{2, \mathrm{sw}}$ to total alkalinity (Signorini et al., 2013). Long Island Sound is not mapped on account of satellite land masking. Annual time series were derived for the identified locations and are shown in Figure 4. 
mean trends due to ocean acidification $\left(\sim 0.012 \pm 0.001 \Omega_{\text {arag }} \mathrm{yr}^{-1}\right.$; Gledhill et al., 2008). Each year, $\Omega_{\text {arag }}$ is enhanced during the spring/summer primarily due to the effects of net community production (net autotrophic) and then is offset in the fall/winter (net heterotrophic), yielding no approximate net change in $\Omega_{\mathrm{arag}}$ across a full annual cycle. Although temperature and salinity exert major controls on $\Omega_{\text {arag }}$ independently, their combined effects (Figure 4) are only minor factors at seasonal or subseasonal time scales relative to the effects of biology. Still, as discussed below, within nearshore/estuarine systems, seasonal (and interannual) changes in freshwater budgets can impart a first-order effect on $\Omega_{\text {arag }}$ that results in episodic corrosive events within estuaries and river plumes (Figure 2). In nearshore/ estuarine systems, carbonate chemistry is more acutely affected at subseasonal time scales relative to offshore waters by net community processes (e.g., Craig et al., in press) and air-sea exchange. Within the shallow mixed layers of the nearshore environments, land-sourced nutrient inputs can drive intense productivity and respiration (Figure 4). This intensified biogeochemistry yields considerable high-frequency variability and large amplitude swings in $\Omega_{\text {arag }}$ relative to Gulf/ Shelf waters. Furthermore, gas exchange plays a much more important role within nearshore environments due to the extreme differences between the sea and air $p \mathrm{CO}_{2}$ that result from these processes. The larger $p \mathrm{CO}_{2}$ differential between air and sea, coupled with a shallow mixed layer depth, can result in a significant $\mathrm{CO}_{2}$ flux. In the case of LIS, this is manifested as $\mathrm{CO}_{2}$ off gassing to the atmosphere in the fall during periods of intense respiration (eutrophication). Conversely, in the western GOM, productivity draws $p \mathrm{CO}_{2, \mathrm{sw}}$ to levels where an influx of atmospheric $\mathrm{CO}_{2}$ is facilitated throughout part of the year, similar to conditions in the Baltic Sea (Thomas and Schneider, 1999).

Thus, while biological productivity/ respiration and seasonality of the hydrologic cycle generally govern short-term variability of the system (subannual), long-term secular changes (e.g., decadal time scales) tend to reflect the influences of large-scale changes in salinity, temperature, and the continued rise in atmospheric $\mathrm{CO}_{2}$ that is either absorbed by the surface waters (i.e., ocean acidification) or, in the case of LIS, retards the off-gassing of $\mathrm{CO}_{2}$. Additionally, decadal trends in nutrient availability, either through changes in the anthropogenic supply or by changes in vertical mixing rates, can also alter the annual mean state of the carbonate system (coastal acidification).

An important area of research is striving to understand how organisms respond to short-term low $\Omega_{\text {arag }}$ events versus long-term changes in $\Omega_{\text {arag }}$. Some marine organisms naturally exposed to low $\Omega_{\text {arag }}$ or highly variable $\Omega_{\text {arag }}$ may be better adapted or acclimated to such conditions. However, we can expect that excursions past critical thresholds caused by short-term carbonate dynamics will become more frequent and persist for longer periods in response to ocean acidification, assuming no change in coastal acidification processes. This latter assumption is likely false and, along with our limited understanding of biological response, contributes to considerable uncertainty in forecasting the long-term impacts of OCA. Coastal processes may also offer an opportunity for local mitigation actions because while only changes in global carbon policies can avert ocean acidification, regional and state policies influence many coastal acidification processes (e.g., nutrient loading, river discharge management).

\section{A BRIEF GEOCHEMICAL TOUR OF THE REGION}

\section{Scotian Shelf Waters}

Understanding the biogeochemistry of the Scotian Shelf waters is critical to improving our understanding of the long-term trends and primary controls of the carbonate chemistry of the GOM. Scotian Shelf waters constitute the northern oceanic boundary of the New England/Nova Scotia region and have been freshening in response to increasing Arctic water outflow since the mid-1960s (Dickson et al., 2003). Outflows from the Gulf of St. Lawrence and the Labrador Shelf Current bring fresher and cooler water onto the Scotian Shelf, which exhibits one of the largest seasonal temperature fluctuations of the world ocean, ranging from subzero temperatures to $20^{\circ} \mathrm{C}$. In winter, due to very cold temperatures, Scotian Shelf waters likely have the lowest carbonate mineral saturation states of the entire New England/ Nova Scotia domain outside of episodic nearshore conditions (Figure 2, Station OA1). After collapse of the spring bloom, seasonal warming and shifts in phytoplankton community composition 
from large diatoms to smaller phytoplankton taxa are the primary controls on the surface $\mathrm{CO}_{2}$ system of Scotian Shelf waters. These smaller taxa facilitate net $\mathrm{CO}_{2}$ uptake in the late spring and summer (Craig et al., in press), further increasing summertime $\Omega_{\text {arag }}$ values relative to what would be anticipated by purely temperature and salinity effects (Figure 4, OA sites). During autumn/ winter, cooling of shelf waters results in water column destratification that can permit corrosive subsurface waters to exchange with the surface (Shadwick et al., 2011; Burt et al., 2013).

\section{Gulf of Maine}

The GOM is a continental shelf sea bounded by Cape Cod and Nova Scotia and separated from the open Atlantic by Georges and Browns Banks. Considerable control of seasonal to interannual circulation patterns is exerted via shelf-sea exchange through the narrow Northeast Channel, which separates Georges and Browns Banks, and from the fresher coastal source waters from along the Scotian Shelf (e.g., Townsend, 1991; Pringle, 2006). Short, but accentuated, spring blooms that occur from late March to early April control the carbonate system of the Gulf/Shelf waters. The supply of freshwater from the Scotian Shelf strongly affects the precise timing and magnitude of these GOM blooms (Head and Sameoto, 2007). The blooms export labile organic carbon into subsurface waters where it is remineralized within the Wilkinson and Jordan Basins over extended residence times (Hopkins and Garfield, 1979), allowing accumulation of DIC-enriched, acidified subsurface waters. Similar to the Scotian Shelf, during autumn/winter, GOM surface waters can exchange with corrosive subsurface waters (Salisbury et al., 2009), resulting in episodic acidification events similar to those reported along the US West Coast during upwelling events. It is not yet known what effect these acidified events may have on marine life in the GOM.

\section{Nearshore Waters of the}

\section{New England/Nova Scotia Region}

The relative vulnerability of a nearshore environment to coastal acidification can vary across the region in part due to the prevailing circulation of a given system. In cases where freshwater is advected laterally along the surface out to sea (e.g., estuarine-type circulation), acidified subsurface waters can be imported from below and affect the surface layer (e.g., Burt et al., 2013). In contrast, other systems (anti-estuarine circulation) accommodate inflows from both offshore surface waters and rivers with outflow occurring in the subsurface through downwelling. Thus, subsurface water characteristics approximate those of surface waters, potentially making them less corrosive relative to estuarine-type systems.

Several moderately sized rivers in the northeast portion of the region, including St. John's, Penobscot, KennebecAndroscoggin, and Merrimack, discharge directly into the counterclockwiseflowing Western Maine Coastal Current, which delivers the freshwater to coastal Maine (Pettigrew et al., 2005; Salisbury et al., 2009). River runoff is greatest from April to July, resulting in extensive river plumes (Geyer et al., 2004) that can generate local corrosive events (Salisbury et al., 2009). Regional precipitation patterns strongly affect the magnitude of these events and are variable from year to year. For example, Figure 5 shows the difference in the distribution of $\Omega_{\text {arag }}$ off Casco Bay, Maine, during June of a relatively dry year (2004) compared to a subsequent wet year (2005). The spatial extent and intensity of undersaturation (i.e., corrosive waters) in the Kennebec River plume is substantially greater during the wetter year.

The significant difference in the corrosive nature of the plume during a wet period may foretell an important concern for coming decades in the New England/Nova Scotia region. One of the most pronounced changes unfolding in the Northeast is in precipitation. Between 1958 and 2010, the amount of precipitation falling in very heavy events
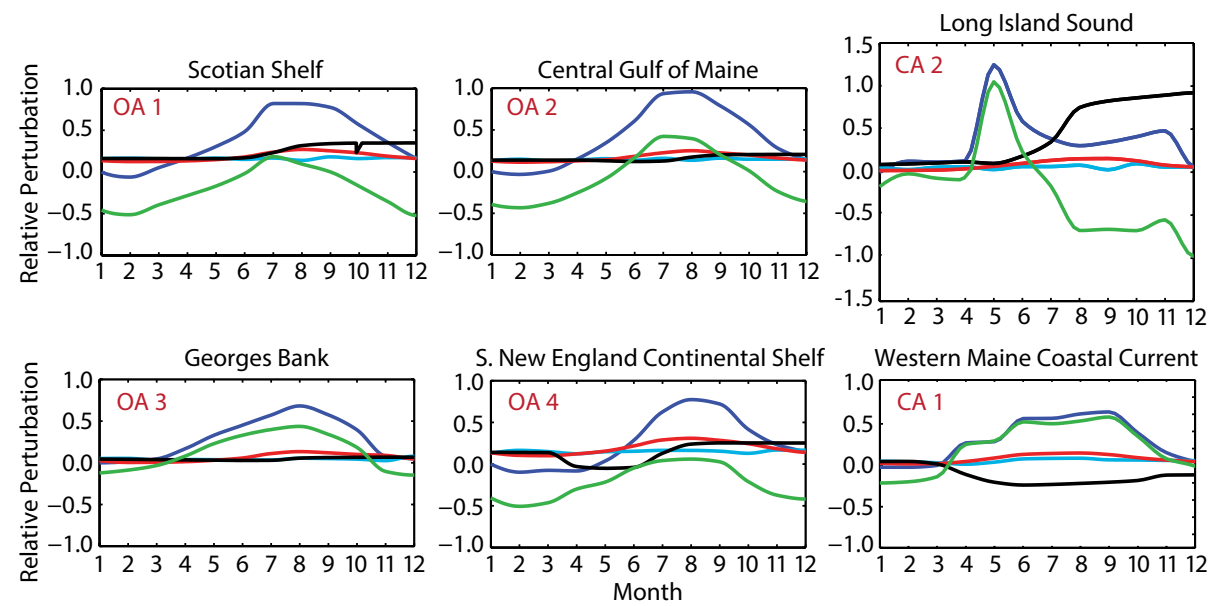

FIGURE 4. Estimates of the seasonal dynamic perturbation in $\Omega$ (blue) at each - Total of the six subregions denoted in Figure 2. The selected locations are representa- - Mixing

tive of the Scotian Shelf (OA1), Central Gulf of Maine (OA2), Georges Bank (OA3), - Air sea flux

New England Continental Shelf (OA4), Western Maine Coastal Current (CA1), and - Biology Long Island Sound (CA2). The relative forcing of lateral mixing (light blue), temperature and salinity (red), air-sea flux (black), and biological productivity/respiration (green) are also shown. In most instances, estimates were derived by solving the carbonic acid system using Signorini et al. (2013) $\mathrm{pCO}_{2, \mathrm{sw}}$ fields paired with ship-based estimates of TA. Long Island Sound (LIS) was derived from monthly composited Environmental Protection Agency $\mathrm{pH}$ data obtained from the central LIS region from 2010 through 2013. The Western Maine Coastal Current station was derived using discrete time series obtained at the Northeastern Regional Association of Coastal Ocean Observing Systems Ocean Acidification Time-series Station. 
(defined as the heaviest $1 \%$ of all daily events) increased more than $70 \%$ in the Northeast, a greater increase in extreme precipitation than any other region in the United States (Horton et al., 2014). In addition, the timing of the winter/spring peak flow dates has shifted a couple of weeks earlier, consistent with shifts in the snow/ice melt timings observed across the region (Hodgkins et al., 2003). This earlier freshet may now co-occur with the period when $\Omega_{\text {arag }}$ values are already near their annual minimum. Under an A2 emissions scenario (for details of the assumptions that go into this scenario, see http://www.ipcc.ch/ipccreports/sres/ emission/index.php?idp=98), a range of model projections averaged over the region suggests a $5 \%$ to $20 \%$ increase in winter precipitation, with the frequency of heavy downpours projected to increase over this century (Kunkel et al., 2013). As a result, we anticipate that the intensity and extent of corrosive river plumes within the nearshore waters of this region will increase over the coming decades.

\section{Urbanized Estuaries of the}

\section{New England/Nova Scotia Region}

The northeastern United States exhibits some of the largest nutrient loading rates in the world (Anderson and Taylor, 2001). Nitrogen inputs can include atmospheric deposition, livestock feed, biological nitrogen fixation, farm fertilizer, and human food. Within watersheds, nitrogen is often filtered to some extent within wetlands and riparian habitats that attenuate its delivery to coastal waters. What does get through, however, can promote primary and secondary production and denitrification within estuaries and coastal water that can drive eutrophication and coastal acidification. Portions of LIS have been observed to exhibit seasonally high $p \mathrm{CO}_{2}$ conditions in excess of 2,500 $\mu \mathrm{atm}$ (Wallace et al., 2014), well above conditions in typical oceanic waters, which are commonly near that of the atmosphere (400 $\mu \mathrm{atm})$. Within the Northeast, the import of nitrogen has gradually increased since the early 1900s (Hale et al., 2013), presumably increasing the export to coastal waters. Roman et al. (2000) found that nitrogen at eight estuaries in the Northeast increased by a factor of over three since

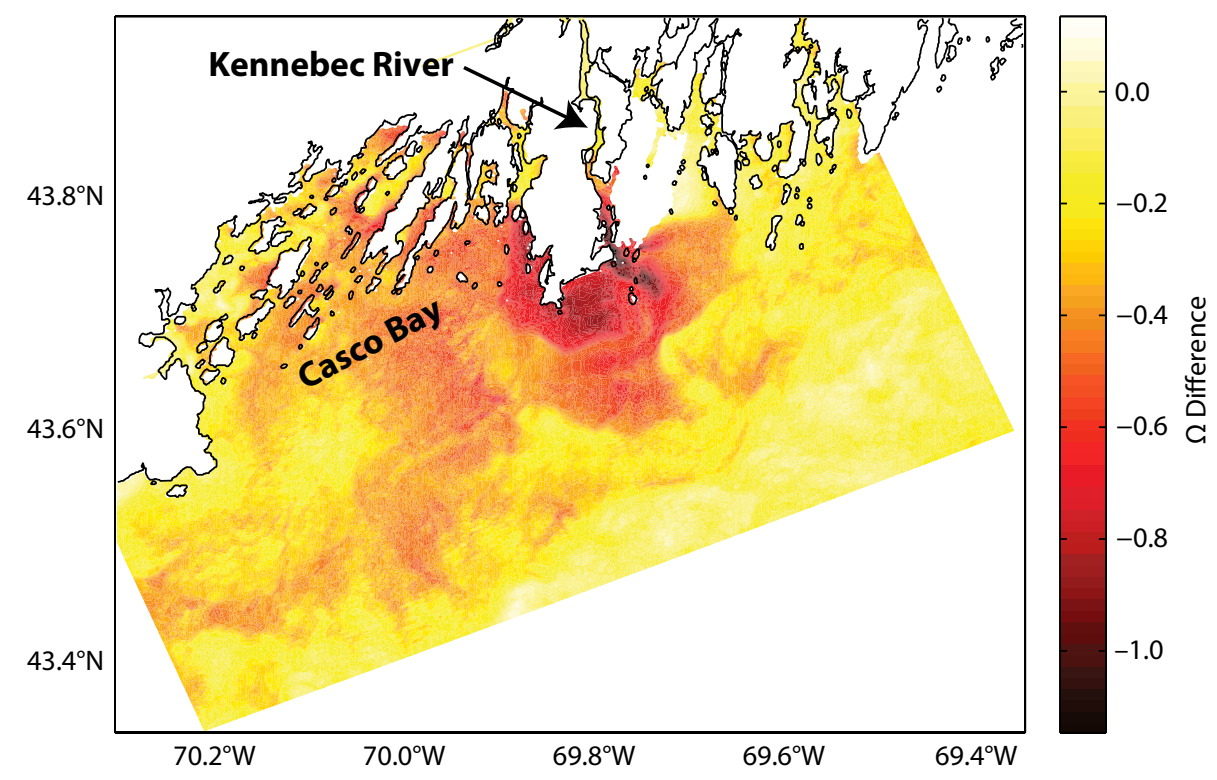

FIGURE 5. Difference in $\Omega_{\text {arag }}$ for a relatively dry year (2004) versus a wet year (2005). The springsummer of 2005 was the wettest in the last two decades. The $\Omega_{\text {arag }}$ was modeled as a function of temperature, salinity, and $p \mathrm{CO}_{2, \text { sw }}$ from data obtained within a month of June 20 . The image shows the effects of regional freshwater discharge, which is expected to increase in the coming decades.
1900, with northern estuaries, such as those in Maine, showing lower average annual concentrations than more southern systems, but continuing to increase due to population growth (Wilson and Fischetti, 2010). Nitrogen loading for Narragansett Bay may have increased by $250 \%$ over the past 150 years due to the increase in the "sewered" human population and the use of agricultural fertilizer (Vadeboncoeur et al., 2010).

There may be cause for optimism in the Northeast, however, given declines in nitrogen loadings due to reductions in imports of livestock feed, and of significant recent decreases in atmospheric deposition (Hale et al., 2013). Improvements to wastewater treatment facilities have reduced loadings to Narragansett Bay by $50 \%$ in the last 15 years by adding biological nutrient removal technology. Furthermore, nitrogen loading to LIS has decreased from about 21 million $\mathrm{kg} \mathrm{yr}^{-1}$ in 1974 to about 14 million $\mathrm{kg} \mathrm{yr}^{-1}$ in 2008. Some of the decline from 1994 to 2008 is related to reductions $(40 \%)$ in nitrogen wet deposition to the watershed. Nitrogen discharges from Connecticut and New York wastewater treatment facilities have also declined, from 85,000 to $61,000 \mathrm{~kg} \mathrm{day}^{-1}$, or 31 million to 22.5 million $\mathrm{kg} \mathrm{yr}^{-1}$ from 1995 to 2010 . The decline is due mostly to a nitrogen credit program undertaken as part of the Long Island Sound Study, in concert with improvements in secondary and tertiary treatment (Latimer et al., 2014).

\section{SUMMARY OF DIRECT BIOLOGICAL RESPONSE TO OCA WITHIN THE NEW ENGLAND/ NOVA SCOTIA REGION}

Marine organisms respond to changing ocean chemistry associated with OCA in a variety of ways. The majority of marine calcifying organisms studied to date show decreased rates of calcification or even dissolution of shells (Fabry et al., 2008), which is understood to result from decreased $\Omega_{\text {arag }}$. However, the increase in $\mathrm{CO}_{2}$ or decrease in $\mathrm{pH}$ can 
affect organisms' acid-base regulation, metabolic rate, immune response, organ development, and olfactory discrimination, among other things. An increase in $p \mathrm{CO}_{2}$ may release photosynthetic organisms from inorganic carbon limitation and actually increase their photosynthetic and growth rates (Koch et al., 2013).
Table 1 summarizes the variety of biological responses that has been observed for various life stages of commercially important New England/Nova Scotia

TABLE 1. Organismal responses of commercially important nearshore New England/Nova Scotia species to increased ocean and coastal acidification (OCA) conditions. Species are listed in order of commercial importance. This table represents a subset of all studies performed on populations originating from the New England/Nova Scotia region using only $\mathrm{pCO}_{2, \mathrm{sw}}$ as the manipulated variable. Responses are indicated in relation to the numbered treatments of each study. Subscripts are used to indicate at which treatment level a significant response was seen, compared to the lowest $p \mathrm{CO}_{2}$ treatment condition, unless otherwise noted. Refer to online Supplemental Table S1 for a complete review of the biological response of New England/ Nova Scotia species or congeners (including noncommercially important species) to OCA, with and without covariables.

\begin{tabular}{|c|c|c|c|c|c|c|c|c|}
\hline \multirow{2}{*}{$\begin{array}{l}\text { Common } \\
\text { Name } \\
\text { Scientific } \\
\text { Name }\end{array}$} & \multicolumn{3}{|c|}{ Treatment levels } & \multirow{2}{*}{$\begin{array}{l}\text { Exposure } \\
\text { Period }\end{array}$} & \multicolumn{3}{|c|}{ Life Stage } & \multirow{2}{*}{$\begin{array}{l}\text { Comments/ } \\
\text { Reference }\end{array}$} \\
\hline & $\begin{array}{l}\mathrm{pCO}_{2} \\
(\mathrm{ppm})\end{array}$ & pH & $\begin{array}{l}\boldsymbol{\Omega}_{\text {Calcite }}\left(\boldsymbol{\Omega}_{\text {cal }}\right) \text { or } \\
\boldsymbol{\Omega}_{\text {Aragonite }}\left(\boldsymbol{\Omega}_{\text {arag }}\right)\end{array}$ & & Larvae & Juveniles & Adults & \\
\hline $\begin{array}{l}\text { American } \\
\text { lobster } \\
\text { Homarus } \\
\text { americanus }\end{array}$ & $\begin{array}{l}\text { 1: } 400 \\
2: 1,200\end{array}$ & $\begin{array}{l}\text { 1: } 8.1 \\
\text { 2: } 7.7\end{array}$ & NR & 13 days & $\begin{array}{l}\text { Days to molt }(\boldsymbol{t}) \text {; } \\
\text { Carapace length }(\boldsymbol{\downarrow})_{2}\end{array}$ & & & Keppel et al., 2012 \\
\hline \multirow{3}{*}{$\begin{array}{l}\text { Soft shell } \\
\text { clam } \\
\text { Mya } \\
\text { arenaria }\end{array}$} & NR & $\begin{array}{l}\text { 1: } 7.32 \\
\text { 2: } 7.04\end{array}$ & $\begin{array}{l}\text { 1: } \Omega_{\text {arag }}=0.53 \\
2: \Omega_{\text {arag }}=0.25\end{array}$ & 18 days & & Recruitment $(\downarrow)_{2}$ & & $\begin{array}{l}\text { In situ manipulations of } \\
\text { sediment } \Omega_{\text {arag. }} \text { pH data are } \\
\text { those of the sediment. } \\
\text { Green et al., } 2009\end{array}$ \\
\hline & NR & NR & $\begin{array}{l}\text { 1: } \Omega_{\text {arag }}=1.3 \\
2: \Omega_{\text {arag }}=0.7\end{array}$ & 35 days & & Recruitment $(\downarrow)_{2}$ & & $\begin{array}{l}\text { In situ manipulations of } \\
\text { sediment } \Omega_{\text {arag. }} \text { pH data are } \\
\text { those of the sediment. } \\
\text { Green et al., } 2013\end{array}$ \\
\hline & NR & $6.8-7.8$ & $\Omega_{\text {arag }}=0.21-1.87$ & 2 hours & & $\begin{array}{l}\text { Burrowing }(\boldsymbol{}) \text {; } \\
\text { Dispersal }(\boldsymbol{\uparrow})\end{array}$ & & Clements and Hunt, 2014 \\
\hline \multirow{6}{*}{$\begin{array}{l}\text { Hard clam } \\
\text { Mercenaria } \\
\text { mercenaria }\end{array}$} & $\begin{array}{l}1: 390 \\
2: 750 \\
3: 1,500\end{array}$ & $\begin{array}{l}\text { 1: } 8.1 \\
2: 7.8 \\
3: 7.5\end{array}$ & $\begin{array}{l}\text { 1: } \Omega_{\text {arag }}=2.37, \Omega_{\text {cal }}=3.68 \\
2: \Omega_{\text {arag }}=1.92, \Omega_{\text {cal }}=2.98 \\
3: \Omega_{\text {arag }}=0.85, \Omega_{\text {cal }}=1.33\end{array}$ & 21 days & $\begin{array}{l}\text { Survival }(\boldsymbol{\downarrow})_{2,3} ; \\
\text { Metamorphosis }(\boldsymbol{\downarrow})_{2,3} \text {; } \\
\text { Growth }(\downarrow)_{2,3}\end{array}$ & & & Talmage and Gobler, 2009 \\
\hline & $\begin{array}{l}\text { 1: } 250 \\
2: 390 \\
3: 750 \\
4: 1,500\end{array}$ & $\begin{array}{l}\text { 1: } 8.2 \\
2: 8.1 \\
3: 7.8 \\
4: 7.5\end{array}$ & $\begin{array}{l}\text { 1: } \Omega_{\text {arag }}=3.42, \Omega_{\text {cal }}=5.31 \\
2: \Omega_{\text {arag }}=2.92, \Omega_{\text {cal }}=4.53 \\
3: \Omega_{\text {arag }}=1.82, \Omega_{\text {cal }}=2.82 \\
4: \Omega_{\text {arag }}=1.08, \Omega_{\text {cal }}=1.67\end{array}$ & 40 days & $\begin{array}{l}\text { Survival }(\downarrow)_{3,4} ; \\
\text { Metamorphosis }(\downarrow)_{3,4} ; \\
\text { Growth }(\downarrow)_{3,4} ; \\
\text { Lipids }(\downarrow)_{3,4} \\
\text { Shell thickness }(\downarrow)_{3,4} \text {; } \\
\text { Shell integrity }(\downarrow)_{3,4}\end{array}$ & & & Talmage and Gobler, 2010 \\
\hline & $\begin{array}{l}\text { 1: } 248 \\
\text { 2: } 373 \\
\text { 3: } 782\end{array}$ & $\begin{array}{l}\text { 1: } 8.20 \\
\text { 2: } 8.08 \\
\text { 3: } 7.80\end{array}$ & $\begin{array}{l}1: \Omega_{\text {arag }}=1.98, \Omega_{\text {cal }}=3.10 \\
2: \Omega_{\text {arag }}=1.53, \Omega_{\text {cal }}=2.59 \\
3: \Omega_{\text {arag }}=0.99, \Omega_{\text {cal }}=1.53\end{array}$ & 10-24 days & $\begin{array}{l}\text { Calcium uptake }(\downarrow)_{2} ; \\
\text { RNA:DNA }(\downarrow)_{3} ; \\
\text { Growth }(\downarrow)_{3} ; \\
\text { Survival }(\downarrow)_{3}\end{array}$ & & & Gobler and Talmage, 2013 \\
\hline & NR & $\begin{array}{l}\text { 1: } 7.8 \\
\text { 2: } 7.1\end{array}$ & $\begin{array}{l}1: \Omega_{\text {arag }}=1.5 \\
2: \Omega_{\text {arag }}=0.3\end{array}$ & 21 days & & Mortality $(\boldsymbol{t})_{2}$ & & Green et al., 2004 \\
\hline & NR & $\begin{array}{l}\text { 1: } 7.9 \\
\text { 2: } 7.3 \\
\text { 3: } 7.0\end{array}$ & $\begin{array}{l}\text { 1: } \Omega_{\text {arag }}=1.6 \\
2: \Omega_{\text {arag }}=0.6 \\
\text { 3: } \Omega_{\text {arag }}=0.4\end{array}$ & $\begin{array}{c}12-25 \\
\text { days }\end{array}$ & & $\begin{array}{l}\text { Survival }(\boldsymbol{t})_{2,3} ; \\
\text { Shell dissolution }(\boldsymbol{t})_{2,3}\end{array}$ & & $\begin{array}{l}\text { pH data provided for } \\
\text { sediment. } \\
\text { Green et al., } 2009\end{array}$ \\
\hline & NR & NR & $\Omega_{\text {arag }}=1.05-0.05$ & 5 minutes & & $\begin{array}{l}\text { Settlement } \\
\text { probability ( } \downarrow \text { ) }\end{array}$ & & $\begin{array}{l}\text { Laboratory experiment. } \\
\text { Settlement probability } \\
\text { decreased with } \\
\text { decreasing sediment } \Omega_{\text {arag, }} \text {, } \\
\text { which correlates with } \\
\text { increasing acidity. } \\
\text { Green et al., } 2013\end{array}$ \\
\hline \multirow[b]{2}{*}{$\begin{array}{l}\text { Eastern } \\
\text { oyster } \\
\text { Crassostrea } \\
\text { virginica }\end{array}$} & $\begin{array}{l}1: 390 \\
2: 750 \\
3: 1,500\end{array}$ & $\begin{array}{l}1: 8.1 \\
2: 7.8 \\
3: 7.5\end{array}$ & $\begin{array}{l}\text { 1: } \Omega_{\text {arag }}=2.37, \Omega_{\text {cal }}=3.68 \\
2: \Omega_{\text {arag }}=1.92, \Omega_{\text {cal }}=2.98 \\
3: \Omega_{\text {arag }}=1.33, \Omega_{\text {cal }}=0.85\end{array}$ & 21 days & $\begin{array}{l}\text { Survival }(\downarrow)_{3} ; \\
\text { Metamorphosis }(\downarrow)_{3} ; \\
\text { Growth }(\downarrow)_{3}\end{array}$ & & & Talmage and Gobler, 2009 \\
\hline & $\begin{array}{l}\text { 1: } 394 \\
2: 745 \\
3: 1,430\end{array}$ & $\begin{array}{l}\text { 1: } 8.1 \\
\text { 2: } 7.9 \\
\text { 3: } 7.7\end{array}$ & $\begin{array}{l}\text { 1: } \Omega_{\text {arag }}=2.77, \Omega_{\text {cal }}=4.27 \\
2: \Omega_{\text {arag }}=1.83, \Omega_{\text {cal }}=2.83 \\
\text { 3: } \Omega_{\text {arag }}=1.1, \Omega_{\text {cal }}=1.69\end{array}$ & 21 days & $\begin{array}{l}\text { Survival }(\leftrightarrow) ; \\
\text { Development }(\boldsymbol{t})_{2,3} ; \\
\text { Shell length }(\downarrow)_{2,3} ; \\
\text { Shell thickness }(\downarrow)_{2,3} ; \\
\text { Lipid content }(\downarrow)_{2,3} ; \\
\text { RNA:DNA }(\boldsymbol{t})_{2,3} ; \\
\text { Calcification }(\downarrow)_{2}\end{array}$ & & & Gobler and Talmage, 2014 \\
\hline
\end{tabular}




\begin{tabular}{|c|c|c|c|c|c|c|c|c|}
\hline \multirow{2}{*}{$\begin{array}{l}\text { Common } \\
\text { Name } \\
\text { Scientific } \\
\text { Name }\end{array}$} & \multicolumn{3}{|c|}{ Treatment levels } & \multirow{2}{*}{$\begin{array}{l}\text { Exposure } \\
\text { Period }\end{array}$} & \multicolumn{3}{|c|}{ Life Stage } & \multirow{2}{*}{$\begin{array}{l}\text { Comments/ } \\
\text { Reference }\end{array}$} \\
\hline & $\begin{array}{l}\mathrm{pCO}_{2} \\
(\mathrm{ppm})\end{array}$ & pH & $\begin{array}{l}\boldsymbol{\Omega}_{\text {Calcite }}\left(\boldsymbol{\Omega}_{\text {cal }}\right) \text { or } \\
\boldsymbol{\Omega}_{\text {Aragonite }}\left(\boldsymbol{\Omega}_{\text {arag }}\right)\end{array}$ & & Larvae & Juveniles & Adults & \\
\hline \multirow[b]{2}{*}{$\begin{array}{l}\text { Summer } \\
\text { flounder } \\
\text { Paralichthys } \\
\text { dentatus }\end{array}$} & $\begin{array}{l}1: 775 \\
2: 1,808 \\
3: 4,714\end{array}$ & $\begin{array}{l}1: 7.8 \\
2: 7.5 \\
3: 7.1\end{array}$ & $\begin{array}{l}1: \Omega_{\text {arag }}=1.28, \Omega_{\text {cal }}=2.07 \\
2: \Omega_{\text {arag }}=0.63, \Omega_{\text {cal }}=1.02 \\
3: \Omega_{\text {arag }}=0.24, \Omega_{\text {cal }}=0.39\end{array}$ & $\begin{array}{l}\text { Embryo } \\
\text { two- } \\
\text { hour post } \\
\text { fertilization } \\
\text { through } \\
\text { hatch }\end{array}$ & $\begin{array}{l}\text { O dph: } \\
\text { Total length }(\mathbf{t})_{2,3} ; \\
\text { Muscular depth }(\mathbf{\uparrow})_{2,3} ; \\
\text { Yolk size }(\boldsymbol{t})_{2,3} ; \\
\text { Oil globular size }(\boldsymbol{t})_{2,3}\end{array}$ & & & Chambers et al., 2014 \\
\hline & $\begin{array}{l}1: 775 \\
2: 1,808 \\
3: 4,714\end{array}$ & $\begin{array}{l}1: 7.8 \\
2: 7.5 \\
3: 7.1\end{array}$ & $\begin{array}{l}1: \Omega_{\text {arag }}=1.28, \Omega_{\text {cal }}=2.07 \\
2: \Omega_{\text {arag }}=0.63, \Omega_{\text {cal }}=1.02 \\
3: \Omega_{\text {arag }}=0.24, \Omega_{\text {cal }}=0.39\end{array}$ & $\begin{array}{l}\text { Larvae } \\
\text { one-day } \\
\text { post hatch } \\
\text { (dph) } \\
\text { through } \\
28 \mathrm{dph} \\
\text { (initiation } \\
\text { of meta- } \\
\text { morphosis) }\end{array}$ & $\begin{array}{l}\text { Larval survival }(\leftrightarrow) ; \\
\mathbf{7} \text { and } \mathbf{1 4} \text { dph: } \\
\text { Total length }(\mathbf{\uparrow})_{2,3} ; \\
\text { muscular depth }(\mathbf{\uparrow})_{2,3} ; \\
\text { mandible size }(\mathbf{\uparrow})_{2,3} ; \\
\mathbf{2 1} \text { dph: } \\
\text { Morphological } \\
\text { measurement }(\leftrightarrow) \text {; } \\
\mathbf{2 8 ~ d p h : ~} \\
\text { Larval size }(\mathbf{\uparrow})_{2} ; \\
\text { Developmental stage }(\mathbf{\uparrow})_{3} ; \\
\text { Lesions of gastrointestinal } \\
\text { tract, pancreas, gill, eye, } \\
\text { kidney, and heart }(\leftrightarrow) ; \\
\text { Liver abnormalities }(\mathbf{\uparrow})_{3}\end{array}$ & & & Chambers et al., 2014 \\
\hline $\begin{array}{l}\text { Atlantic } \\
\text { longfin } \\
\text { squid } \\
\text { Doryteuthis } \\
\text { pealeii }\end{array}$ & $\begin{array}{l}1: 390 \\
2: 2,200\end{array}$ & $\begin{array}{l}1: 7.9 \\
2: 7.3\end{array}$ & $\begin{array}{l}1: \Omega_{\text {arag }}=1.68 \\
2: \Omega_{\text {arag }}=0.52\end{array}$ & 20 days & $\begin{array}{l}\text { Hatching time }(\uparrow)_{2} ; \\
\text { Mantle length }(\downarrow)_{2} ; \\
\text { Statolith area }(\downarrow)_{2} ; \\
\text { Statolith condition }(\downarrow)_{2}\end{array}$ & & & Kaplan et al., 2013 \\
\hline \multirow{5}{*}{$\begin{array}{l}\text { Bay scallop } \\
\text { Argopecten } \\
\text { irradians }\end{array}$} & $\begin{array}{l}1: 390 \\
2: 750 \\
3: 1500\end{array}$ & $\begin{array}{l}1: 8.1 \\
2: 7.8 \\
3: 7.5\end{array}$ & $\begin{array}{l}1: \Omega_{\text {arag }}=3.06, \Omega_{\text {cal }}=4.8 \\
2: \Omega_{\text {arag }}=1.87, \Omega_{\text {cal }}=2.9 \\
3: \Omega_{\text {arag }}=0.91, \Omega_{\text {cal }}=1.41\end{array}$ & 21 days & $\begin{array}{l}\text { Survival }(\downarrow)_{2,3} \text {; } \\
\text { Metamorphosis }(\downarrow)_{2,3} \text {; } \\
\text { Growth }(\downarrow)_{2,3}\end{array}$ & & & Talmage and Gobler, 2009 \\
\hline & $\begin{array}{l}\text { 1: } 250 \\
2: 390 \\
\text { 3: } 750 \\
\text { 4: } 1500\end{array}$ & $\begin{array}{l}1: 8.2 \\
2: 8.1 \\
3: 7.8 \\
4: 7.5\end{array}$ & $\begin{array}{l}1: \Omega_{\text {arag }}=3.34, \Omega_{\text {cal }}=5.18 \\
2: \Omega_{\text {arag }}=2.94, \Omega_{\text {cal }}=4.55 \\
\text { 3: } \Omega_{\text {arag }}=1.81, \Omega_{\text {cal }}=2.81 \\
4: \Omega_{\text {arag }}=1.07, \Omega_{\text {cal }}=1.66\end{array}$ & 40 days & $\begin{array}{l}\text { Survival }(\downarrow)_{3,4} \text {; } \\
\text { Metamorphosis }(\downarrow)_{3,4} \text {; } \\
\text { Growth }(\downarrow)_{3,4} \text {; } \\
\text { Lipids }(\downarrow)_{3,4} \text {; } \\
\text { Shell thickness }(\downarrow)_{3,4} \text {; } \\
\text { Shell integrity }(\downarrow)_{3,4}\end{array}$ & & & Talmage and Gobler, 2010 \\
\hline & $\begin{array}{l}\text { 1: } 509 \\
2: 1987\end{array}$ & $\begin{array}{l}1: 7.9 \\
2: 7.4\end{array}$ & $\begin{array}{l}1: \Omega_{\text {arag }}=2.26 \\
2: \Omega_{\text {arag }}=0.74\end{array}$ & 7 days & $\begin{array}{l}\text { Survival }(\downarrow)_{2} \\
\text { Shell length }(\downarrow)_{2}\end{array}$ & & & White et al., 2013 \\
\hline & $\begin{array}{l}1: 480 \\
2: 2600\end{array}$ & $\begin{array}{l}1: 8.0 \\
2: 7.3\end{array}$ & $\begin{array}{l}1: \Omega_{\text {arag }}=2.5-2.7 \\
2: \Omega_{\text {arag }}=0.6-0.7\end{array}$ & 7 days & $\begin{array}{l}\text { Survival }(\downarrow)_{2} \text {; } \\
\text { Shell length }(\downarrow)_{2}\end{array}$ & & & White et al., 2014 \\
\hline & $\begin{array}{l}1: 237 \\
2: 397 \\
3: 753\end{array}$ & $\begin{array}{l}1: 8.20 \\
2: 8.08 \\
3: 7.81\end{array}$ & $\begin{array}{l}1: \Omega_{\text {arag }}=1.89, \Omega_{\text {cal }}=2.94 \\
2: \Omega_{\text {arag }}=1.71, \Omega_{\text {cal }}=2.6 \\
3: \Omega_{\text {arag }}=1.01, \Omega_{\text {cal }}=1.55\end{array}$ & $\begin{array}{l}15-35 \\
\text { days }\end{array}$ & $\begin{array}{l}\text { Calcium uptake }(\downarrow)_{2} \text {; } \\
\text { RNA:DNA }(\downarrow)_{2,3} ; \\
\text { Growth }(\downarrow)_{3} ; \\
\text { Survival }(\downarrow)_{2}\end{array}$ & Growth $(\downarrow)_{2}$ & & Gobler and Talmage, 2013 \\
\hline
\end{tabular}

SYMBOL EXPLANATIONS: NR = Not reported; $\uparrow=$ Significant positive response to increased $p \mathrm{CO}_{2}$; $\downarrow=$ Significant negative response to increased $p C \mathrm{O}_{2}$; $\leftrightarrow=$ No significant response to increased $\mathrm{pCO}_{2}$

species. Although generally the benthicliving adults are harvested, typically only the planktonic early life stages of commercially important organisms have been studied with respect to OCA in this region. Online Supplemental Table S1 further summarizes observed responses for different life stages of all New England/ Nova Scotia species and congeners that have been studied with respect to OCA. Organisms may respond to changes in any of the carbonate system parameters, including increased $p \mathrm{CO}_{2}$, decreased $\mathrm{pH}$, or decreased $\Omega_{\text {arag. }}$. Different organisms or even different biological responses of the same organism may be affected more by one parameter than by another. Therefore, in Tables 1 and $\mathrm{S} 1$, we report $p \mathrm{CO}_{2}, \mathrm{pH}$, and $\Omega_{\text {arag }}$ whenever possible, but throughout this discussion, we have used the carbonate chemistry parameter that is, to our best understanding, most relevant to the organism or the process being discussed. However, even in instances where the biology is not directly responding to $\Omega_{\text {arag }}$, we still urge the community of researchers considering biological responses to OCA to be mindful to report $\Omega_{\text {arag }}$ because this will ensure that the carbonate system is fully described as needed for comparative purposes.

Because organisms can adapt or acclimate to OCA conditions, their responses to OCA may depend on the conditions, and on the variability of those conditions, that they currently encounter. Coastal carbonate chemistry can vary on hourly (tidal), daily (photosynthesis/respiration cycles), and seasonal (seasonal microbial 
respiration) time scales. Carbonate variability within different time scales can impact different biological functions. For example, hourly or daily variability could impact respiration or net calcification, while seasonal variability could impact fecundity, larval development, and settlement processes. Without a highresolution observing network to monitor existing carbonate chemistry over these various time scales, it is difficult to predict how organisms in the New England/ Nova Scotia region will respond to future OCA. The observed responses of marine species in the New England/Nova Scotia region to increased $p \mathrm{CO}_{2}$ conditions (decreased $\mathrm{pH}$ and $\Omega_{\text {arag }}$ ) are based mainly on single species, single stressor laboratory experiments (Table 1; online Supplemental Table S1). The majority of these studies were performed on populations from outside of the New England/ Nova Scotia region. There have not been any studies using New England/ Nova Scotia native populations living primarily in the Gulf and Shelf waters. In the following text, we provide a brief synopsis of research findings to date.

\section{OCA Effects on Mollusks}

As calcifiers, mollusks are at particular risk from OCA. Among New England/ Nova Scotia bivalve species tested (regardless of source population), all but the ocean quahog Artica islandica are negatively affected, exhibiting slowed shell growth and/or calcification, sometimes across multiple life stages. While most juvenile and adult bivalves in this region seem capable of surviving OCA until it reaches extreme levels $\left(p \mathrm{CO}_{2}>3,500 \mu \mathrm{atm}\right)$, the larval stages are highly sensitive. Though these high $p \mathrm{CO}_{2}$ levels may seem extreme, current nearshore/coastal processes regularly yield similar values, particularly within urbanized estuaries, and clearly represent waters undersaturated with respect to aragonite (i.e., $\left.\Omega_{\text {arag }}<1.0\right)$. Specifically, larval stages of the hard clam (Mercenaria mercenaria), eastern oyster (Crassostrea virginica), and bay scallop (Argopecten irradians) show elevated mortality at moderate-to-high levels of $\mathrm{CO}_{2}$ (750-1,500 $\mu$ atm $p \mathrm{CO}_{2}$ ). Further, larvae of these species surviving high $\mathrm{CO}_{2}$ (low $\Omega_{\text {arag }}$ ) exposure are smaller and generally less fit, life-history characteristics that would likely translate into high mortality rates among early stage juveniles (Marshall et al., 2003). The high sensitivity of larvae to OCA could represent a bottleneck for individuals exposed to this stressor (Schneider et al., 2003). This individual effect could translate into strong population-level effects in species for which population dynamics are sensitive to larval survival. Similarly, low biological sensitivity in adults can also translate into population-level effects for species exhibiting population dynamics that are strongly dependent on adult survival (i.e., long-lived species).

\section{OCA Effects on Crustaceans}

Crustaceans represent a commercially and ecologically valuable group of species in the New England/Nova Scotia region. However, commercially important crustaceans from this region have rarely been studied with respect to OCA. The only two studies on the American lobster (Homarus americanus) found opposite effects of $\mathrm{pCO}_{2}$ on different life stages. Keppel et al. (2012) found a negative impact on larval carapace length, while Ries et al. (2009) found a positive impact on juvenile calcification. Ries et al. (2009) also reported the same result for two other decapod crustacean taxa, blue crabs (Callinectes sapidus) and shrimp (Penaeus plebejus). The consistent positive responses of the three decapod taxa to elevated $\mathrm{CO}_{2}$ in Ries et al. (2009) set them apart from other invertebrates and fishes that responded negatively to acidification in that study. However, the two studies of the American lobster to date have questionable relevance to natural conditions, as they were conducted at temperatures above the normal range that the majority of lobsters in the New England/ Nova Scotia region would encounter for any prolonged period of time.

The effects of increased $\mathrm{CO}_{2}$ on adult crustacean survival appear to be speciesand life stage-specific. In some cases, the effect is population-specific. Population specificity appears to be related to the natural variability of local carbonate conditions, with populations naturally exposed to highly variable conditions less likely to be affected by OCA (Pansch et al., 2014). Therefore, the source population used in a study is an important factor when considering OCA effects on New England/ Nova Scotia species as the responses of populations within this region may differ from those observed for populations from other regions.

\section{OCA Effects on Other}

\section{Benthic Invertebrates}

Many studies have focused on the sensitivity of echinoderms, while research on other taxonomic groups of benthic invertebrates is scant to absent. Of the echinoderms, the green sea urchin Strongylocentrotus droebachiensis has received the most attention. While the vast majority of studies have considered only adults, the effects on the green urchin are overwhelmingly negative at all life stages. Only Dupont et al. (2013) have considered multiple life stages of the green sea urchin in the same experiment, showing that carry-over effects can exacerbate the negative impact of high $\mathrm{CO}_{2}$ (low $\Omega_{\text {arag }}$ ) on larvae and juveniles, but this is only one study and linkages between life stages need to be further tested.

Among non-echinoderm benthic invertebrates, a general trend is that noncalcifying species fare better than calcifying species. For example, the noncalcifying annelid clam worm Alitta virens was not affected by reduced seawater $\mathrm{pH}$ (Widdicombe and Needham, 2007), but annelids forming calcium carbonate tubes (Spirorbis spirobis and Hydroides spp.) showed negative effects (Ries et al., 2009; Lane et al., 2013; Saderne and Wahl, 2013).

\section{OCA Effects on Finfish}

Only four finfish species from the New England/Nova Scotia region have been examined for OCA effects to date, 
and only one of them, summer flounder (Paralichthys dentatus), is significantly commercially exploited. Chambers et al. (2014) found that summer flounder embryonic survival was significantly reduced by exposure to increased $\mathrm{pCO}_{2}$ conditions. Naturally, summer flounder egg buoyancy varies with the specific gravity of the seawater and with variations in the composition of eggs, especially lipid to non-lipid ratio, resulting in eggs being found anywhere from 10-110 m, depending on the season. Although growth and developmental rates were altered, larval survival was unaffected.

Atlantic cod (Gadus morhua) has been examined for OA effects more extensively than any North Atlantic fish species but only with fish sourced from the northeastern Atlantic. Using offspring from a population of cod from the Baltic Sea-a region of relatively low $\Omega_{\text {arag }}$-Frommel et al. $(2010,2013)$ found either no or very modest effects on cod sperm, embryos, and young larvae. Working with offspring from a population of cod from the Norwegian coast, however, Frommel et al. (2012) and Maneja et al. (2013a,b) found a variety of negative effects on older larvae, highlighting the possible importance of differences in population source, duration of exposure, and developmental stages inspected to the observed response.

Murray et al. (2014) evaluated the influence of natural variation in water chemistry and parental experience in the susceptibility of offspring to elevated $\mathrm{CO}_{2}$ levels. Offspring of Atlantic silverside obtained from adults collected early in the spring spawning season at relatively low $\mathrm{CO}_{2}$ levels had reduced survival and growth when challenged with elevated $\mathrm{CO}_{2}$ levels in the laboratory. In contrast, offspring from adults collected later in the spring-concurrent with seasonally increasing $\mathrm{CO}_{2}$ levels-were decreasingly susceptible to the same experimental laboratory $\mathrm{CO}_{2}$ conditions.

When effects of high $\mathrm{CO}_{2}$ exposure are expressed in finfish, they are often sublethal, even at the highest $\mathrm{CO}_{2}$ levels. Sublethal should not be misinterpreted as insignificant. Often, sublethal effects have longer-term consequences on population health through a cascade of indirect ecological effects. Furthermore, the original habitat of test species, specifically the natural variability in water carbonate chemistry, may be predictive of a species' vulnerability to future OCA. As the above examples of cod and Atlantic silverside show, fish that currently occupy habitats of naturally low and variable $\Omega_{\text {arag }}$ may be more tolerant of future OCA, illustrating the need for a more comprehensive observing system to better characterize and monitor contemporary carbonate chemistry conditions in coastal regions.

\section{OCA Effects on Zooplankton}

Copepods and pteropods are the two groups of zooplankton most often studied in relation to OCA because they are important food sources for higher trophic levels. Within the copepod literature, the trend has been to use extremely high $p \mathrm{CO}_{2}$ levels (up to $>10,000 \mathrm{ppm}$ ), with the rationale that these levels represent conditions of leakage from potential carbon sequestration sites. Copepods appear to be relatively robust to atmospheric $p \mathrm{CO}_{2}$ levels up to about 3,500 ppm $(\Omega<1.0)$. For example, Calanus finmarchicus survival is not affected by $p \mathrm{CO}_{2}$ levels less than 7,000 ppm (Pedersen et al., 2013, 2014) and survival of Acartia tonsa copepodites and adults is not affected by $p \mathrm{CO}_{2}$ levels less than 3,000 ppm, although the A. tonsa naupliar mortality rate increases at 1,000 $\mu \mathrm{atm}$ (Cripps et al., 2014). In contrast to copepods, pteropods are highly sensitive to increased $p \mathrm{CO}_{2}$ conditions (Bednaršek et al., 2014). In particular, calcification is negatively affected at both the larval and adult life stages. Furthermore, shell dissolution has been shown at larval, juvenile, and adult life stages. Smaller shells or shells with reduced integrity due to dissolution will have ecological (food web) impacts for pteropods.

\section{OCA Effects on Phytoplankton}

Phytoplankton play an important role in modulating short-term variability in carbonate chemistry. In addition, many organisms of socioeconomic importance in the New England/Nova Scotia region rely directly and/or indirectly on phytoplankton for nutrition, and OCA may alter the nutritional value of phytoplankton (Rossoll et al., 2012). Diets composed of phytoplankton with elevated molar ratios of C:P and N:P or low in essential polyunsaturated fatty acids (PUFAs) as a result of prey exposure to OCA conditions could potentially result in deleterious effects on development and growth of grazers due to poor nutritional quality (Sargent et al., 1999; Sterner and Elser, 2002; Martin et al., 2008).

In laboratory unialgal experiments, responses of phytoplankton growth rates to OA appear to be species-specific and includes increases, decreases, or no significant change to those rates. In a series of experiments with phytoplankton species commonly found in the New England/ Nova Scotia region, there was generally no change in growth rates between present-day and year 2100 predicted $\mathrm{CO}_{2}$ levels (750-1,000 $\mu \mathrm{atm}$; Andrew King, Norwegian Institute for Water Research, pers. comm., August 30, 2014).

Phytoplankton cultures grown at high $\mathrm{CO}_{2}$ levels generally show either no change or $\sim 10-40 \%$ higher C:P and N:P molar ratios (Hutchins et al., 2009). Several species from the NECAN study area also reflect this pattern, with diatoms not exhibiting a significant change in C:P and $\mathrm{N}: \mathrm{P}$ molar ratios when grown at elevated $\mathrm{CO}_{2}$ levels. Several species, however, had significantly lower C:P and higher N:P ratios when grown at geological maxima $\mathrm{CO}_{2}$ levels $\left(\sim 3,000-4,000 \mu\right.$ atm $\left.p \mathrm{CO}_{2}\right)$, which may also represent levels experienced within contemporary nearshore environments where episodic coastal acidification events can occur.

Relatively little is known about the influence of $\mathrm{CO}_{2}$ on essential PUFAS that are synthesized by phytoplankton. Elevated $\mathrm{CO}_{2}$ levels (750-1,000 $\mu$ atm $p \mathrm{CO}_{2, \mathrm{sw}}$ ) were shown to result in a $\sim 50 \%$ decrease in nutritious PUFAs in a diatom species (Rossoll et al., 2012) and a slight increase 
$(\sim 5 \%)$ in PUFAs in a natural assemblage from outside the New England/ Nova Scotia region (Leu et al., 2013).

\section{OCA Effects on Macrophytes}

Unlike invertebrate and finfish species whose responses to OCA have been documented on populations sourced from within the New England/Nova Scotia region, there are no published OA studies using macrophyte (macroalgae and seagrass) populations from within this region; most work has been done using populations from the Pacific Northwest or from Europe. Our limited ability to predict how New England/Nova Scotia macrophytes will respond to OA is additionally complicated by the variety of physiological processes that can potentially be directly affected by elevated seawater $p \mathrm{CO}_{2}$. It is difficult to generalize response trends among the 28 New England/Nova Scotia conspecifics investigated from other regions. Nonetheless, there are consistent trends across two major functional groups (i.e., calcareous species vs. "fleshy" algae and marine plants) to $\mathrm{CO}_{2}$ enrichment among macrophyte species from the NECAN study area. The vulnerability of calcareous algae and the increased productivity among fleshy algae and marine plants in response to elevated $p \mathrm{CO}_{2}$ are consistent with several meta-analyses from other ecosystems (Kroeker et al., 2010, 2013; Johnson et al., 2014).

Each of the region's six coralline species studied responded negatively to $p \mathrm{CO}_{2}$ elevation in terms of maintaining structural integrity of calcareous tissue. However, there was a mixed response across species for various parameters of photosynthetic performance. Only certain aspects of photosynthesis (e.g., maximum relative electron transport rate and light saturation points) were enhanced by $\mathrm{CO}_{2}$ enrichment in a two-week study of Corallina officinalis (Yildiz et al., 2013); otherwise, the remaining species, exposed for longer periods to treatment conditions, experienced no change or reduction in photosynthetic capacity.

Among the fleshy algae and marine plant species in this region, the responses to elevated $p \mathrm{CO}_{2}$ were largely positive. Ten of the 14 species examined grew faster (or added more biomass) under treatment conditions, while the remainder were unaffected or lost overall biomass. Interestingly, the two kelp species that lost biomass during these experiments (Saccharina latissima and Fucus vesiculosus) are economically important species in the NECAN study area and globally. Faster growth rate may be attributed to release from inorganic carbon limitations (Koch et al., 2013).

\section{Other Considerations of \\ Biological Response to OCA}

The vast majority of studies on the biological responses of NECAN study area species have focused on a single life stage of an organism without considering links between different developmental stages of the organism's life cycle or the role that parental exposure may play in the organismal response. Such multilife-stage and even multigenerational studies will be essential in order to project the population's response to OCA (see Breitburg et al., 2015, in this issue). The few studies that have considered multiple life stages make it clear that examining biological response through multiple life stages provides insight into later-stage responses that would not have been seen with single-life stage experiments (e.g., McDonald et al., 2009; Gobler and Talmage, 2013). Furthermore, maternal exposure to stressful environmental conditions during gametogenesis can affect investment in reproduction, influencing offspring survival and fitness (Marshall et al., 2008). In the context of OCA, effects of maternal exposure have rarely been considered, except in studies of copepods. Thus, examination of maternal effects among non-copepod species in the NECAN study area remains an important research priority.

In addition to OCA, in the coming century marine organisms will face additional stressors, including rising temperature, declining oxygen levels, and decreasing salinity (Doney et al., 2012). As a result, studies focused on OCA alone may be inadequate for predicting how NECAN ecosystems will respond to climate change. Breitburg et al. (2015, in this issue) provide examples of synergistic and antagonistic impacts of multiple stressors including OCA on marine organisms and suggest multiple stressor research priorities.

Knowing how an organism responds to OCA is not the same as being able to predict how an ecosystem will respond. In the NECAN study area, research has been primarily limited to single-species experiments and a few mesocosm studies. Few controlled experimental studies of $\mathrm{OA}$ at higher levels of organization (e.g., community and ecosystem) have been conducted. The uncertainty associated with scaling from single-species studies to ecosystem-level effects is explored by Busch et al. (2015, in this issue). A more robust strategic approach that includes ecosystem-level, multispecies designs; takes advantage of natural $\mathrm{CO}_{2}$ gradients in marine habitats; and integrates results from laboratory and field experiments is needed in order to better understand and predict ecosystem responses to future $\mathrm{CO}_{2}$ conditions (Andersson et al., 2015, in this issue).

\section{KEY KNOWLEDGE GAPS AND RESEARCH NEEDS}

In its infancy, the field of research into the biological response to increased $\mathrm{CO}_{2}$ has focused largely on single-species, singlestressor, single-life stage, laboratorybased experiments. In order to more accurately forecast how changing $p \mathrm{CO}_{2}$ conditions will affect the New England/ Nova Scotia region's ecosystems, it is time to move beyond these limited-focus studies. We propose the following topics, in no particular order, as research priorities for understanding biological responses in the New England/Nova Scotia region to OCA conditions.

- Studies on commercially important species to evaluate their sensitivity to OCA conditions, including 
American lobster (Homarus americanus), blue crab (Callinectes sapidus), Jonah crab (Cancer borealis), rock crab (Cancer irroratus), horseshoe crab (Limulus polyphemus), sea scallop (Placopecten magellanicus), and many species of finfish, using populations from within the NECAN study area.

- Multistressor studies considering increased $p \mathrm{CO}_{2}$ (decreased $\Omega_{\text {arag }}$ ) combined with one or more other stressors such as temperature, hypoxia, salinity, ultraviolet exposure, or trace metal exposure (see Breitburg et al., 2015, in this issue) specific to this region.

- Multiple life-stage and/or multigenerational studies that follow one or more organisms through multiple life stages exposed to increased $p \mathrm{CO}_{2}$ (see Breitburg et al., 2015, in this issue).

- Trophic interaction/indirect effect studies that consider how species' interactions with other species or with their environments may change as a result of increased $p \mathrm{CO}_{2}$

- Studies considering species responses to variable $\mathrm{pCO}_{2}$ conditions to better reflect conditions in nature.

- Process investigations to quantify the relative magnitude of the effects of each of the primary forcing agents (airsea exchange, upwelling, river/stream, estuary, benthic/pelagic biology, vertical mixing) on $\Omega_{\text {arag }}$ dynamics and trends across the region.

- Climate-quality monitoring of the net changes in carbonate chemistry using a strategic design that permits quantifying net changes in the dominant forcing terms, including the boundary conditions (e.g., Scotian Shelf chemistry, upwelling waters, rivers).

- Establish carbonate chemistry long-term trends across the region including hindcasting to the preindustrial period, forecasting impending conditions at weekly to seasonal scales, and projecting long-term changes in carbonate chemistry under IPCC scenarios.

- Field studies to help us move from single-species effects to ecosystem effects and improve our understanding of how OCA affects organisms in their natural environments.

\section{Regional Capacity to Bring to Bear} Considerable OCA research and monitoring capacity is available in the New England/Nova Scotia region includes laboratories, OA monitoring buoys and stations, and Ocean Survey Vessel (OSV) sampling locations and continuous underway monitoring, all of which provide biological and/or carbonate chemistry data relevant to OCA modeling and research (Figure 6). However, with the exception of a few fixed autonomous stations, the sampling frequency throughout much of the region is too low to adequately capture short-term episodic events that could pose more acute, immediate concerns to impacted industries and managers. As an example, the East Coast Ocean Acidification (ECOA, 2015) cruise (purple dashed line and diamonds in Figure 6) represents a reoccupation of prior Gulf of Mexico and East Coast Carbon Cruises (GOMECC, 2007, 2012), and, while it offers considerable spatial coverage, it is scheduled to be repeated only once every four years. Furthermore, even in cases where high-frequency observations are being recorded, they typically measure only one carbon parameter (e.g., $p \mathrm{CO}_{2}$ ) and do not permit real-time determination of $\Omega_{\mathrm{arag}}$. The coverage is also heterogeneous throughout the region. For example, within a $20 \mathrm{~km}$ radius of Portsmouth, $\mathrm{NH}$, three stations monitor the full water column, whereas the closest station to the whole State of Rhode Island is at the Martha's Vineyard Coastal Observatoryover $70 \mathrm{~km}$ away and monitoring only near the bottom. To date, most observing efforts have emphasized surface over subsurface measurements as a consequence of cost and technical feasibility, despite the fact that many of the impacted species may reside in the benthos. The few short-duration, time-series studies that document subsurface conditions (i.e., at Stellwagen Bank; Salisbury et al., 2012) reveal important coupling between surface blooms and subsurface remineralization, whereby enhanced saturation states in the surface, which may be beneficial to some organisms, may yield corrosive conditions in the subsurface. So full water column monitoring can be an important

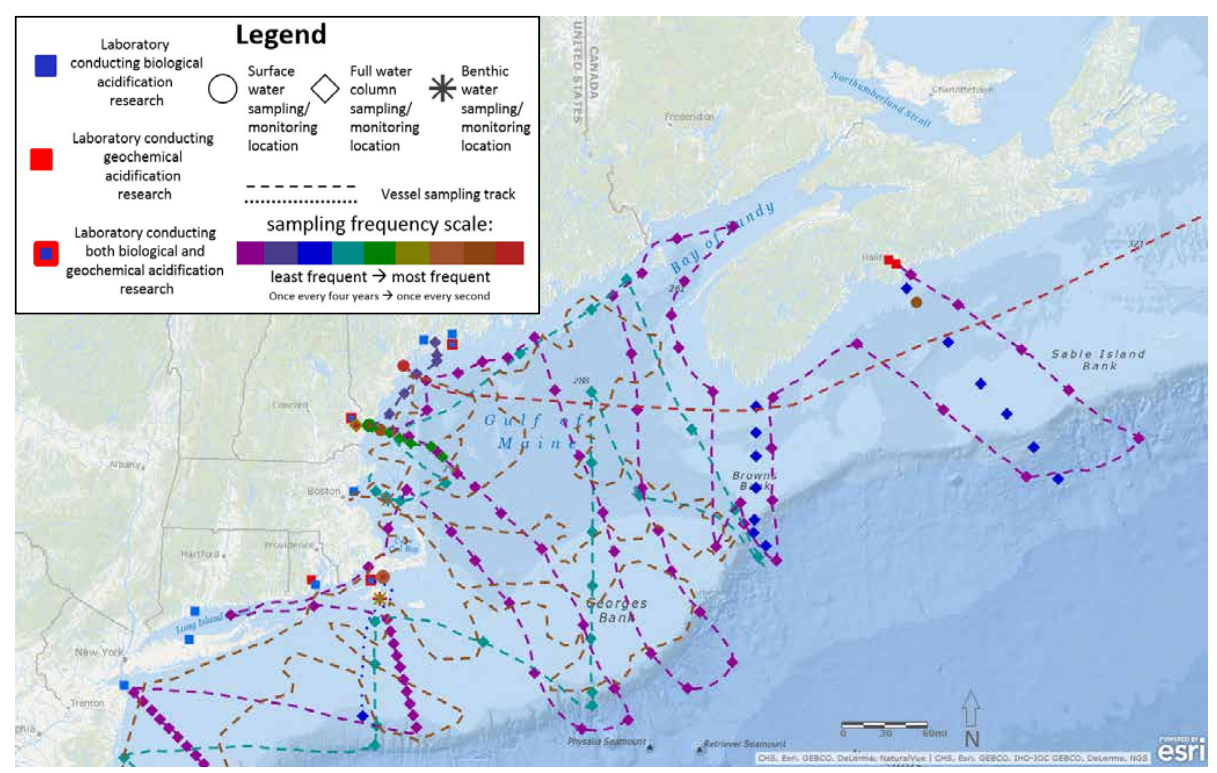

FIGURE 6. Existing capacity for ocean acidification research and monitoring in the New England/ Nova Scotia region. Shown are laboratories researching ocean acidification (red squares), along with its effects on biology (blue squares). Monitoring of carbonate chemistry parameters by buoys and vessels and approximate cruise tracks and sampling waypoints are color coded according to frequency of observation/reoccupation. 
requirement in some instances.

In order to better understand how OCA is unfolding throughout the NECAN study area, a more comprehensive observing system is needed to provide enhanced spatial and temporal coverage as well as subsurface monitoring capability. This system will require leveraging existing capacity as well as creating opportunity for expansion of the system. NECAN is already working toward improving the research and monitoring community network by bringing together project managers from government, academia, and industry to synthesize regional data that can aid in recommending regional priorities. While not intended as a data repository, NECAN encourages its members to leverage existing observational networks (e.g., Northeastern Regional Association of Coastal Ocean Observing Systems, NERACOOS) in order to meet the emerging needs of the research and stakeholder communities.

Recommendations for advancing research include taking advantage of ships of opportunity, volunteer observing programs, and equipping already in-place buoys with additional sensors. In order to understand the system as a whole, monitoring must be conducted at multiple depths throughout the region as well as leveraged for additional data through all possible avenues.

\section{CONCLUSIONS}

The NECAN study area represents a system at potentially elevated risk to continued OCA in coming years. The poorly buffered waters of the region will likely grow increasingly sensitive to acute carbonate chemistry perturbations on account of increasing amounts of freshwater supplied through Arctic outflow to the north and due to increases in winter precipitation (both driven by climate change). These freshening trends could more frequently result in corrosive river plumes exhibiting greater spatial extent over time. However, in both nearshore and Gulf/Shelf systems, the effects of net community production are significant in controlling short-term carbonate dynamics, and without improved predictive capacity for how nitrogen, carbon, and phosphorus inputs will change over time, we will be challenged to accurately forecast ocean and coastal acidification. Furthermore, considerable uncertainty remains with regard to how the NECAN ecosystems will respond to OCA. There is an urgent need to greatly expand OCA monitoring capacity and biological response studies that are most relevant to the New England/Nova Scotia region and better couple these studies to an enhanced observing system that better characterizes the contemporary dynamics of the system. @

SUPPLEMENTARY MATERIALS. Supplemental Methods and Supplemental Table S1 are available online at http://www.tos.org/oceanography/archive/ 28-2_gledhill.html.

ACKNOWLEDGMENTS. NECAN thanks the presenters of the NECAN webinar series and participants at the state-of-science workshop for thoughtful insights. For a complete listing of participants and contributors, please consult the NECAN website (http:// www.neracoos.org/necan). NECAN is coordinated in part by NERACOOS (http://www.neracoos.org), with funding from the National Oceanic and Atmospheric Administration (NOAA) US Integrated Ocean Observing System (IOOS) Award \#NA11NOS0120034. This project was supported in part by an appointment to the Internship/Research Participation Program at the Office of Water, US Environmental Protection Agency (EPA), administered by the Oak Ridge Institute for Science and Education through an interagency agreement between the US Department of Energy and the EPA. JS acknowledges support from NASA grant from NNX14AL84G NASA-CCS. The scientific results and conclusions, as well as any views or opinions expressed herein, are those of the authors and do not necessarily reflect the views of any of the federal agencies with which any of the contributing authors may be affiliated.

\section{REFERENCES}

Andersson, A.J., D.I. Kline, P.J. Edmunds, S.D. Archer, N. Bednaršek, R.C. Carpenter, M. Chadsey, P. Goldstein, A.G. Grottoli,

T.P. Hurst, and others. 2015. Understanding ocean acidification impacts on organismal to ecological scales. Oceanography 28(2):16-27, http://dx.doi.org/10.5670/oceanog.2015.27.

Anderson, T.H., and G.T. Taylor. 2001. Nutrient pulses, plankton blooms, and seasonal hypoxia in western Long Island Sound. Estuaries 24:228-243, http://dx.doi.org/10.2307/1352947.

Barton, A., G.G. Waldbusser, R.A. Feely, S.B. Weisberg, J.A. Newton, B. Hales, S. Cudd, B. Eudeline, C.J. Langdon, I. Jefferds, and others. 2015. Impacts of coastal acidification on the Pacific Northwest shellfish industry and adaptation strategies implemented in response. Oceanography 28(2):146-159, http://dx.doi.org/10.5670/oceanog.2015.38.

Bednaršek, N., R.A. Feely, J.C.P. Reum, B. Peterson, J. Menkel, S.R. Alin, and B. Hales. 2014. Limacina helicina shell dissolution as an indicator of declining habitat suitability owing to ocean acidification in the California Current Ecosystem. Proceedings of the Royal Society B 281:20140123, http://dx.doi.org/ $10.1098 /$ rspb.2014.0123.
Bourque, B.J., B. Johnson, and R.S. Steneck. 2007. Possible prehistoric hunter-gatherer impacts on food web structure in the Gulf of Maine. Pp. 165-187 in Human Impacts on Ancient Marine Environments. J. Erlandson and R. Torben, eds, University of California Press, Berkeley, CA.

Breitburg, D.L., J. Salisbury, J.M. Bernhard, W.-J. Cai, S. Dupont, S.C. Doney, K.J. Kroeker, L.A. Levin, W.C. Long, L.M. Milke, and others. 2015. And on top of all that... Coping with ocean acidification in the midst of many stressors. Oceanography 28(2):48-61, http://dx.doi.org/10.5670/oceanog.2015.31.

Burt, W., H. Thomas, and J.-P. Auclair. 2013. Shortlived radium isotopes on the Scotian Shelf: Unique distribution and tracers of cross-shelf $\mathrm{CO}_{2}$ and nutrient transport. Marine Chemistry 156:120-129, http://dx.doi.org/10.1016/j.marchem.2013.05.007.

Busch, D.S., M.J. O'Donnell, C. Hauri, K.J. Mach,

M. Poach, S.C. Doney, and S.R. Signorini. 2015. Understanding, characterizing, and communicating responses to ocean acidification: Challenges and uncertainties. Oceanography 28(2):30-39, http://dx.doi.org/10.5670/oceanog.2015.29.

Chambers, R.C., A.C. Candelmo, E.A. Habeck, M.E. Poach, D. Wieczorek, K.R. Cooper, C.E. Greenfield, and B.A. Phelan. 2014. Effects of elevated $\mathrm{CO}_{2}$ in the early life stages of summer flounder, Paralichthys dentatus, and potential consequences of ocean acidification. Biogeosciences 11:1,613-1,626, http://dx.doi.org/ 10.5194/bg-11-1613-2014.

Clements, J.C., and H.L. Hunt. 2014. Influence of sediment acidification and water flow on sediment acceptance and dispersal of juvenile soft-shell clams (Mya arenaria L.). Journal of Experimental Marine Biology and Ecology 453:62-69, http://dx.doi.org/10.1016/j.jembe.2014.01.002. Costanza, R., R. d'Arge, R. de Groot, S. Farber, M. Grasso, B. Hannon, K. Limburg, S. Naeem, R.V. O'Neill, J. Paruelo, and others. 1997. The value of the world's ecosystem services and natural capital. Nature 387:253-260, http://dx.doi.org/ $10.1038 / 387253 a 0$.

Craig, S.E., H. Thomas, C.T. Jones, W.K.W. Li B.J.W. Greenan, E.H. Shadwick, and W.J. Burt. In press. The effect of seasonality in phytoplankton community composition on $\mathrm{CO}_{2}$ uptake on the Scotian Shelf. Journal of Marine Systems, http://dx.doi.org/10.1016/j.jmarsys.2014.07.006

Cripps, G., P. Lindeque, and K. Flynn. 2014. Have we been underestimating the effects of ocean acidification on zooplankton? Global Change Biology 20:3,377-3,385, http://dx.doi.org/10.1111/ gcb.12582.

Dickson, R.R., R. Curry, and I. Yashayaev. 2003. Recent changes in the North Atlantic. Philosophical Transactions of the Royal Society of London A 361:1,917-1,934, http://dx.doi.org/10.1098/ rsta.2003.1237.

Doney, S.C., V.J. Fabry, R.A. Feely, and J.A. Kleypas. 2009. Ocean acidification: The other $\mathrm{CO}_{2}$ problem. Annual Review of Marine Science 1:169-192, http://dx.doi.org/10.1146/ annurev.marine.010908.163834.

Doney, S.C., M. Ruckelshaus, J.E. Duffy, J.P. Barry, F. Chan, C.A. English, H.M. Galindo, J.M. Grebmeier, A.B. Hollowed, N. Knowlton, and others. 2012. Climate change impacts on marine ecosystems. Annual Review of Marine Science 4:11-37, http://dx.doi.org/10.1146/ annurev-marine-041911-111611.

Dupont, S., N. Dorey, M. Stumpp, F. Melzner, and M. Thorndyke. 2013. Long-term and trans-lifecycle effects of exposure to ocean acidification in the green sea urchin Strongylocentrotus droebachiensis. Marine Biology 160:1,835-1,843, http://dx.doi.org/10.1007/s00227-012-1921-x.

Ekstrom, J., L. Suatoni, S. Cooley, L. Pendleton, G.G. Waldbusser, J. Cinner, J. Ritter, C. Langdon, R. van Hooidonk, D. Gledhill, and others. 2015. Vulnerability and adaptation of US shellfisheries to ocean acidification. Nature Climate Change 5:207-214, http://dx.doi.org/10.1038/ nclimate2508. 
Fabry, V.J., B.A. Seibel, R.A. Feely, and J.C. Orr. 2008. Impacts of ocean acidification on marine fauna and ecosystem processes. ICES Journal of Marine Science 65:414-432, http://dx.doi.org/10.1093/ icesjms/fsn048.

Fratantoni, P.S., T. Holzwarth-Davis, C. Bascuñán, and M.H. Taylor. 2013. Description of the 2012 Oceanographic Conditions on the Northeast U.S. Continental Shelf. United States Department of Commerce, Northeast Fisheries Science Center Reference Document 13-26, National Marine Fisheries Service, Woods Hole, MA, 40 pp.

Friedrich, T., A. Timmermann, A. Abe-Ouchi, N.R. Bates, M.O. Chikamoto, M.J. Church, J.E. Dore, D.K. Gledhill, M. Gonzalez-Davila, M. Heinemann, and others. 2012. Detecting regional anthropogenic trends in ocean acidification against natural variability. Nature Climate Change 2:167-171, http://dx.doi.org/10.1038/nclimate1372.

Frommel, A.Y., R. Maneja, D. Lowe, A.M. Malzahn, A.J. Geffen, A. Folkvord, U. Piatkowski, T.B.H. Reusch, and C. Clemmesen. 2012. Severe tissue damage in Atlantic cod larvae under increasing ocean acidification. Nature Climate Change 2:42-46, http://dx.doi.org/10.1038/ nclimate1324.

Frommel, A.Y., A. Schubert, U. Piatkowski, and C. Clemmesen. 2013. Egg and early larval stages of Baltic cod, Gadus morhua, are robust to high levels of ocean acidification. Marine Biology 160:1,825-1,834, http://dx.doi.org/10.1007/ s00227-011-1876-3.

Frommel, A.Y., V. Stiebens, C. Clemmesen, and J. Havenhand. 2010. Effect of ocean acidification on marine fish sperm (Baltic cod: Gadus morhua). Biogeosciences 7:3,915-3,919, http://dx.doi.org/ 10.5194/bg-7-3915-2010.

Gledhill, D., R. Wanninkhof, and M. Eakin. 2009 Observing ocean acidification from space. Oceanography 22(4):48-59, http://dx.doi.org/ 10.5670/oceanog.2009.96

Gledhill, D.K., R. Wanninkhof, F.J. Millero, and M. Eakin. 2008. Ocean acidification of the Greater Caribbean Region 1996-2006. Journal of Geophysical Research 113, C10031, http://dx.doi.org/10.1029/2007JC004629.

Geyer, W.R., P.S. Hill, and G.C. Kineke. 2004. The transport, transformation and dispersal of sediment by buoyant coastal flows. Continental Shelf Research 24:927-949, http://dx.doi.org/10.1016/ j.csr.2004.02.006.

Gobler, C.J., and S.C. Talmage. 2013. Short-and long-term consequences of larval stage exposure to constantly and ephemerally elevated carbon dioxide for marine bivalve populations. Biogeosciences 10:2,241-2,253, http://dx.doi.org/ 10.5194/bg-10-2241-2013.

Gobler, C.J., and S.C. Talmage. 2014. Physiological response and resilience of early life-stage Eastern oysters (Crassostrea virginica) to past, present and future ocean acidification. Conservation Physiology 2:cou004, http://dx.doi.org/10.1093/ conphys/cou004.

Green, M.A., M.E. Jones, C.L. Boudreau, R.L. Moore, and B.A. Westman. 2004. Dissolution mortality of juvenile bivalves in coastal marine deposits. Limnology and Oceanography 49:727-734, http://dx.doi.org/10.4319/lo.2004.49.3.0727.

Green, M.A., G.G. Waldbusser, L. Hubazc, E. Cathcart, and J. Hall. 2013. Carbonate mineral saturation state as the recruitment cue for settling bivalves in marine muds. Estuaries and Coasts 36:18-27, http://dx.doi.org/10.1007/s12237-012-9549-0.

Green, M.A., G.G. Waldbusser, S.L. Reilly, and K. Emerson. 2009. Death by dissolution: Sediment saturation state as a mortality factor for juvenile bivalves. Limnology and Oceanography 54:1,037-1,047, http://dx.doi.org/ 10.4319/lo.2009.54.4.1037.

Hale, R.L., J.H. Hoover, W.M. Wollheim, and C.J. Vörösmarty. 2013. History of nutrient inputs to the northeastern United States, 1930-2000. Global Biogeochemical Cycles27:578-591, http://dx.doi.org/10.1002/gbc.20049.
Head, E.J.H., and D.D. Sameoto. 2007. Inter-decadal variability in zooplankton and phytoplankton abundance on the Newfoundland and Scotian shelves. Deep-Sea Research Part /l 54:2,686-2,701, http://dx.doi.org/10.1016/j.dsr2.2007.08.003.

Hodgkins, G.A., R.W. Dudley, and T.G. Huntington. 2003. Changes in the timing of high river flows in New England over the 20th Century. Journal of Hydrology 278:244-252, http://dx.doi.org/10.1016/ S0022-1694(03)00155-0.

Hopkins, T.S., and N. Garfield III. 1979. Gulf of Maine intermediate waters. Journal of Marine Research 37:103-139.

Horton, R., G. Yohe, W. Easterling, R. Kates, M. Ruth, E. Sussman, A. Whelchel, D. Wolfe, and F. Lipschultz. 2014. Northeast. Pp. 371-395 in Climate Change Impacts in the United States: The Third National Climate Assessment J.M. Melillo, T.C. Richmond, and G.W. Yohe, eds, United States Global Change Research Program.

Hutchins, D.A., M.R. Mulholland, and F. Fu. 2009. Nutrient cycles and marine microbes in a $\mathrm{CO}_{2}$ enriched ocean. Oceanography 22(4):128-145, http://dx.doi.org/10.5670/oceanog.2009.103.

Johnson, M.D., V.W. Moriarty, and R.C. Carpenter. 2014. Acclimatization of the crustose coralline alga Porolithon onkodes to variable $p \mathrm{CO}_{2}$. PLOS ONE 9(2):e87678, http://dx.doi.org/10.1371/ journal.pone.0087678.

Kaplan, M.B., T.A. Mooney, D.C. McCorkle, and A.L. Cohen. 2013. Adverse effects of ocean acidification on early development of squid (Doryteuthis pealeii). PLoS ONE 8:e63714, http://dx.doi.org/ 10.1371/journal.pone.0063714.

Keppel, E.A., R.A. Scrosati, and S.C. Courtenay. 2012 Ocean acidification decreases growth and development in American lobster (Homarus americanus) larvae. Journal of Northwest Atlantic Fisheries Science 44:61-66, http://dx.doi.org/10.2960/ J.v44.m683.

Koch, M., G. Bowes, C. Ross, and X.H. Zhang. 2013. Climate change and ocean acidification effects on seagrasses and marine macroalgae. Global Change Biology 19:103-132, http://dx.doi.org/10.1111/j.1365-2486.2012.02791.x.

Kroeker, K.J., R.L. Kordas, R.N. Crim, I.E. Hendriks, L. Ramajo, G.S. Singh, C.M. Duarte, and J.-P. Gattuso. 2013. Impacts of ocean acidification on marine organisms: Quantifying sensitivities and interaction with warming. Global Change Biology 19:1,884-1,896, http://dx.doi.org/10.1111/ gcb.12179.

Kroeker, K.J., R.L. Kordas, R.N. Crim, and G.G. Singh. 2010. Meta-analysis reveals negative yet variable effects of ocean acidification on marine organisms. Ecology Letters 13:1,419-1,434 http://dx.doi.org/10.1111/j.1461-0248.2010.01518.x.

Kunkel, K.E., L.E. Stevens, S.E. Stevens, L. Sun, E. Janssen, D. Wuebbles, J. Rennells, A. DeGaetano, and J.G. Dobson. 2013. Regional Climate Trends and Scenarios for the U.S. National Climate Assessment: Part 1. Climate of the Northeast U.S. NOAA Technical Report NESDIS 142-1, National Oceanic and Atmospheric Administration, National Environmental Satellite, Data, and Information Service, Washington, DC 87 pp., http://www.nesdis.noaa.gov/technical_ reports/NOAA_NESDIS_Tech_Report_142-1Climate_of_the_Northeast_U.S.pdf.

Lane, A.C., J. Mukherjee, V.B.S. Chan, and V. Thiyagarajan. 2013. Decreased $\mathrm{pH}$ does not alter metamorphosis but compromises juvenile calcification of the tube worm Hydroides elegans. Marine Biology 160:1,983-1,993, http://dx.doi.org/10.1007/ s00227-012-2056-9.

Latimer, J.S., M.A. Tedesco, R.L. Swanson, C. Yarish, P.E. Stacey, and C. Garza, eds. 2014. Long Island Sound: Prospects for the Urban Sea. Springer Series on Environmental Management, 539 pp.

Leu, E., M. Daase, K.G. Schulz, A. Stuhr, and U. Riebesell. 2013. Effect of ocean acidification on the fatty acid composition of a natural plankton community. Biogeosciences 10:1,143-1,153, http://dx.doi.org/10.5194/bg-10-1143-2013.

Maneja, R.H., A.Y. Frommel, H.I. Browman, C. Clemmese, A.J. Geffen, A. Folkvord, U. Piatowski, C.M.F. Durif, R. Bjelland, and A.B. Skiftesvik. 2013a. The swimming kinematics of larval Atlantic cod, Gadus morhua L., are resilient to elevated seawater $\mathrm{pCO}_{2}$. Marine Biology 160:1,963-1,972, http://dx.doi.org/10.1007/ s00227-012-2054-y.

Maneja, R.H., A.Y. Frommel, A.J. Geffen, A. Folkvord, U. Piatkowski, M.Y. Chang, and C. Clemmesen. 2013b. Effects of ocean acidification on the calcification of otoliths of larval Atlantic cod Gadus morhua. Marine Ecology Progress Series 477:251-258, http://dx.doi.org/10.3354/ meps10146.

Marshall, D.J., R. Allen, and A. Crean. 2008. The ecological and evolutionary importance of maternal effects in the sea. Oceanography and Marine Biology 46:203-250, http://dx.doi.org/ 10.1201/9781420065756.ch5.

Marshall, D.J., T.F. Bolton, and M.J. Keough. 2003. Offspring size affects the post-metamorphic performance of a colonial marine invertebrate. Ecology 84:3,131-3,137, http://dx.doi.org/ 10.1890/02-0311

Martin, R.E., A. Quigg, and V. Podkovyrov. 2008. The evolution of ocean stoichiometry and diversification of the marine biosphere. Palaeogeography, Palaeoclimatology, Palaeoecology 258:277-291.

McDonald, M.R., J.B. McClintock, C.D. Amsler,

D. Rittschof, R.A. Angus, B. Orihuela, and K. Lutostanski. 2009. Effects of ocean acidification over the life history of the barnacle Amphibalanus amphitrite. Marine Ecology Progress Series 385:179-187, http://dx.doi.org/10.3354/ meps08099.

McLaughlin, K., S.B. Weisberg, A.G. Dickson, G.E. Hofmann, J.A. Newton, D. AseltineNeilson, A. Barton, S. Cudd, R.A. Feely, I.W. Jefferds, and others. 2015. Core principles of the California Current Acidification Network: Linking chemistry, physics, and ecological effects. Oceanography 28(2):160-169, http://dx.doi.org/10.5670/oceanog.2015.39.

Morse, J.W., R.S. Arvidson, and A. Luttge. 2007. Calcium carbonate formation and dissolution. Chemical Reviews 107, 342e381, http://dx.doi.org/ $10.1021 / \mathrm{cr050358j}$.

Murray, C.S., A. Malvezzi, C.J. Gobler, and H. Baumann. 2014. Offspring sensitivity to ocean acidification changes seasonally in a coastal marine fish. Marine Ecology Progress Series 504:1-11, http://dx.doi.org/10.3354/meps10791.

NMFS (National Marine Fisheries Service). 2014 Commercial Fisheries Statistics: Annual Commercial Landing Statistics. National Oceanic and Atmospheric Administration, http://www.st.nmfs.noaa.gov/commercial-fisheries/ commercial-landings/annual-landings.

Orr, J.C., V.J. Fabry, O. Aumont, L. Bopp, S.C. Doney, R.A. Feely, A. Gnanadesikan, N. Gruber, A. Ishida F. Joos, and others. 2005. Anthropogenic ocean acidification over the twenty-first century and its impact on the calcifying organisms. Nature 437:681-686, http://dx.doi.org/10.1038/ nature04095.

Pansch, C., I. Schaub, J. Havenhand, and M. Wahl. 2014. Habitat traits and food availability determine the response of marine invertebrates to ocean acidification. Global Change Biology 40:765-777, http://dx.doi.org/10.1111/gcb.12478.

Pedersen, S.A., B.H. Hansen, D. Altin, and A.J. Olsen. 2013. Medium-term exposure of the North Atlantic copepod Calanus finmarchicus (Gunnerus, 1770) to $\mathrm{CO}_{2}$-acidified seawater: Effects on survival and development. Biogeosciences 10:7,481-7,491, http://dx.doi.org/10.5194/bg-10-7481-2013.

Pedersen, S.A., V.T. Våge, A.J. Olsen, K.M. Hammer, and D. Altin. 2014. Effects of elevated carbon dioxide $\left(\mathrm{CO}_{2}\right)$ concentrations on early developmental stages of the marine copepod Calanus finmarchicus Gunnerus (Copepoda: Calanoidae). Journal of Toxicology and Environmental Health, Part A 77:535-549, http://dx.doi.org/10.1080/15287 394.2014.887421.

Pettigrew, N.R., J.H. Churchill, C.D. Janzen, L.J. Mangum, R.P. Signell, A.C. Thomas, D.W. Townsend, J.P. Wallinga, and J.H. Xue. 2005. The kinematic and hydrographic structure of the Gulf of Maine Coastal Current. Deep Sea Research Part // 52:2,369-2,391, http://dx.doi.org/10.1016/ j.dsr2.2005.06.033. 
Pringle, J.M. 2006. Sources of variability in Gulf of Maine circulation, and the observations needed to model it. Deep Sea Research Part // 53:2,457-2,476, http://dx.doi.org/10.1016/ j.dsr2.2006.08.015.

Ries, J.B., A.L. Cohen, and D.C. McCorkle. 2009. Marine calcifiers exhibit mixed responses to $\mathrm{CO}_{2}$ induced ocean acidification. Geology 37:1,131-1,134, http://dx.doi.org/10.1130/G30210A.1.

Roman, C.T., N. Jaworski, F.T. Short, S. Findlay, and R.S. Warren. 2000. Estuaries of the northeastern United States: Habitat and land use signatures. Estuaries:23(6):743-764.

Rossoll, D., R. Bermudez, H. Hauss, K.G. Schulz, U. Riebesell, U. Sommer, and M. Winder. 2012. Ocean acidification-induced food quality deterioration constrains trophic transfer. PLOS ONE 7:e34737, http://dx.doi.org/10.1371/ journal.pone.0034737.

Saderne, V., and M. Wahl. 2013. Differential responses of calcifying and non-calcifying epibionts of a brown macroalga to present-day and future upwelling $\mathrm{PCO}_{2}$. PLoS ONE 8(7):e70455, http://dx.doi.org/ 10.1371/journal.pone.0070455.

Salisbury, J., M. Green, C. Hunt, and J. Campbell. 2008. Coastal acidification by rivers: A threat to shellfish? Eos, Transactions American Geophysical Union 89:513-514, http://dx.doi.org/ 10.1029/2008EO500001

Salisbury, J., D. Vandemark, A. Mahadevan, B. Jonsson, C. Hunt, and W.R. McGillis. 2009. Episodic riverine influence on surface DIC in the coastal Gulf of Maine. Estuarine, Coastal and Shelf Science 82:108-118, http://dx.doi.org/10.1016/ j.ecss.2008.12.021

Salisbury, J., D. Vandemark, C. Pilsklan, B. CowieHaskell, and K. Newhall. 2012. Monitoring Ocean Acidification in Deep Waters of the Stellwagen Bank National Marine Sanctuary: A Progress Report. US Department of Commerce, National Oceanic and Atmospheric Administration, Office of National Marine Sanctuaries, Stellwagen Bank National Marine Sanctuary.

Sargent, J., G. Bell, L. McEvoy, D. Tocher, and A. Estévez. 1999. Recent developments in the essential fatty acid nutrition of fish. Aquaculture 177:191-199, http://dx.doi.org/10.1016/ S0044-8486(99)00083-6.

Schneider, D.W., J.A. Stoeckel, C.R. Rehmann, K.D. Blodgett, R.E. Sparks, and D.K. Padilla. 2003. A developmental bottleneck in dispersing larvae: Implications for spatial population dynamics. Ecology Letters 6:352-360, http://dx.doi.org/10.1046/j.1461-0248.2003.00443.x.

Shadwick, E.H., H. Thomas, K. Azetsu-Scott, B.J.W. Greenan, E. Head, and E. Horne. 2011 Seasonal variability of dissolved inorganic carbon and surface water $p \mathrm{CO}_{2}$ in the Scotian Shelf region of the Northwestern Atlantic. Marine Chemistry 124:23-37, http://dx.doi.org/10.1016/ j.marchem.2010.11.004

Signorini, S.R., A. Mannino, R.G. Najjar Jr., M.A.M. Friedrichs, W.-J. Cai, J. Salisbury, Z.A. Wang, H. Thomas, and E. Shadwick. 2013. Surface ocean $\mathrm{pCO}_{2}$ seasonality and sea-air $\mathrm{CO}_{2}$ flux estimates for the North American east coast. Journal of Geophysical Research 118:5,439-5,460, http://dx.doi.org/10.1002/jgrc.20369.

Steneck, R.S., T.P. Hughes, J.E. Cinner, W.N. Adger, S.N. Arnold, F. Berkes, S.A. Boudreau, K. Brown, C. Folke, L. Gunderson, and others. 2011. Creation of a gilded trap by the high economic value of the Maine lobster fishery. Conservation Biology 25:904-912, http://dx.doi.org/ 10.1111/j.1523-1739.2011.01717.x.

Sterner, R.W., and J.J. Elser. 2002. Ecological Stoichiometry: The Biology of Elements From Molecules to the Biosphere. Princeton University Press, Princeton, NJ, 464 pp.

Strong, A.L., K.J. Kroeker, L.T. Teneva, L.A. Mease, and R.P. Kelly. 2014. Ocean acidification 2.0: Managing our changing coastal ocean chemistry. BioScience 64:581-592, http://dx.doi.org/10.1093/ biosci/biu072.

Takahashi, T., S.C. Sutherland, D.W. Chipman, J.G. Goddard, T. Newberger, and C. Sweeney. 2014 Climatological Distributions of $\mathrm{pH}, \mathrm{pCO}_{2}$, Total $\mathrm{CO}_{2}$, Alkalinity, and $\mathrm{CaCO}_{3}$ Saturation in the Global
Surface Ocean. ORNL/CDIAC-160, NDP-094. Carbon Dioxide Information Analysis Center, Oak Ridge National Laboratory, US Department of Energy, Oak Ridge, TN, 41 pp.

Talmage, S.C., and C.J. Gobler. 2009. The effects of elevated carbon dioxide concentrations on the metamorphosis, size, and survival of larval hard clams (Mercenaria mercenaria), bay scallops (Argopecten irradians), and Eastern oysters (Crassostrea virginica). Limnology and Oceanography 54:2,072-2,080, http://dx.doi.org/10.4319/lo.2009.54.6.2072.

Talmage, S.C., and C.J. Gobler. 2010. Effects of past, present, and future ocean carbon dioxide concentrations on the growth and survival of larval shellfish. Proceedings of the National Academy of Sciences of the United States of America 107:17,246-17,251, http://dx.doi.org/10.1073/ pnas.0913804107.

Thomas, H., and B. Schneider. 1999. The seasonal cycle of carbon dioxide in Baltic Sea surface waters. Journal of Marine Systems 22:53-67, http://dx.doi.org/10.1016/S0924-7963(99)00030-5.

Townsend, D.W. 1991. Influences of oceanographic processes on the biological productivity of the Gulf of Maine. Reviews in Aquatic Sciences 5:211-230.

Vadeboncoeur, M.A., S.P. Hamburg, and

D. Pryor. 2010. Modeled nitrogen loading to Narragansett Bay: 1850 to 2015. Estuaries and Coasts 33:1,113-1,127, http://dx.doi.org/10.1007/ s12237-010-9320-3.

Waldbusser, G.G., B. Hales, C.K. Langdon, B.A. Haley, P. Schrader, E.L. Brunner, M.W. Gray, C.A. Miller, and I. Gimenez. 2015. Saturation-state sensitivity of marine bivalve larvae to ocean acidification. Nature Climate Change 5:273-280, http://dx.doi.org/10.1038/nclimate2479.

Waldbusser, G.G., and J.E. Salisbury. 2014. Ocean acidification in the coastal zone from an organism's perspective: Multiple system parameters, frequency domains, and habitats. Annual Review of Marine Science 2014. 6:221-47, http://dx.doi.org/ 10.1146/annurev-marine-121211-172238

Wallace, R.B., H. Baumann, J.S. Grear, R.C. Aller, and C.J. Gobler. 2014. Coastal ocean acidification: The other eutrophication problem. Estuarine, Coastal and Shelf Science 148:1-13, http://dx.doi.org/ 10.1016/j.ecss.2014.05.027.

Wang, Z.A., R. Wanninkhof, W.-J. Cai, R.H. Byrne, X. Hu, T.-H. Peng, and W.-J. Huang. 2013. The marine inorganic carbon system along the Gulf of Mexico and Atlantic coasts of the United States: Insights from a transregional coastal carbon study. Limnology and Oceanography 58:325-342, http://dx.doi.org/10.4319/lo.2013.58.1.0325.

White, M.M., D.C. McCorkle, L.S. Mullineaux, and A.L. Cohen. 2013. Early exposure of bay scallops (Argopecten irradians) to high $\mathrm{CO}_{2}$ causes a decrease in larval shell growth. PLOS ONE 8:e61065, http://dx.doi.org/10.1371/ journal.pone.0061065.

White, M.M., L.S. Mullineaux, D.C. McCorkle, and A.L. Cohen. 2014. Elevated $p \mathrm{CO}_{2}$ exposure during fertilization of the bay scallop Argopecten irradian reduces larval survival but not subsequent shell size. Marine Ecology Progress Series 498:173-186, http://dx.doi.org/10.3354/meps10621.

Widdicombe, S., and H.R. Needham. 2007. Impact of $\mathrm{CO}_{2}$-induced seawater acidification on the burrowing activity of Nereis virens and sediment nutrient flux. Marine Ecology Progress Series 341:111-122, http://dx.doi.org/10.3354/meps341111.

Wilson, S.G., and T.R. Fischetti. 2010. Coastline Population Trends in the United States: 1960 to 2008. United States Department of Commerce, Economics and Statistics Administration, United States Census Bureau, Report P25-1139, Washington, DC, 28 pp.

Yildiz, G., L.C. Hofmann, K. Bischof, and S. Dere. 2013. Ultraviolet radiation modulates the physiological responses of the calcified rhodophyte Corallina officinalis to elevated $\mathrm{CO}_{2}$. Botanica Marina 56:161-168, http://dx.doi.org/10.1515/ bot-2012-0216.
Zeebe, R. 2012. History of seawater carbonate chemistry, atmospheric $\mathrm{CO}_{2}$, and ocean acidification. Annual Review of Earth and Planetary Sciences 40:141-165, http://dx.doi.org/10.1146/ annurev-earth-042711-105521.

AUTHORS. Dwight K. Gledhill (dwight.gledhill@ noaa.gov) is Deputy Director, National Oceanic and Atmospheric Administration (NOAA) Ocean Acidification Program, Silver Spring, MD, USA Meredith M. White is Postdoctoral Research Scientist, Bigelow Laboratory for Ocean Sciences, East Boothbay, ME, USA. Joseph Salisbury is Research Associate Professor, Ocean Processes Analysis Laboratory, University of New Hampshire, Durham, $\mathrm{NH}$, USA. Helmuth Thomas is Professor, Department of Oceanography, Dalhousie University, Halifax, NS, Canada. Ivy Mlsna is Oak Ridge Institute for Science Education Fellow, Office of Water, US Environmental Protection Agency (US EPA) Region 1, Boston, MA, USA Matthew Liebman is Environmental Biologist, US EPA Region 1, Boston, MA, USA. Bill Mook is President, Mook Seafarm Inc., Walpole, ME, USA. Jason Grear is Research Ecologist, Population Ecology Branch, US EPA, Narragansett, RI, USA. Allison C. Candelmo is Postdoctoral Research Associate, NOAA Northeast Fisheries Science Center (NEFSC), Sandy Hook, NJ, USA. R. Christopher Chambers is Research Fishery Biologist, NOAA NEFSC, Sandy Hook, NJ, USA. Christopher J. Gobler is Professor, School of Marine and Atmospheric Sciences, Stony Brook University, Stony Brook, NY, USA. Christopher W. Hunt is PhD Candidate, Natural Resources \& Earth Systems Science PhD Program, University of New Hampshire, Durham, NH, USA. Andrew L. King is Research Scientist, Norwegian Institute for Water Research, Oslo, Norway. Nichole N. Price is Senior Research Scientist, Bigelow Laboratory for Ocean Sciences, East Boothbay, ME, USA. Sergio R. Signorini is Senior Scientist, Science Applications International Corporation, NASA Goddard Space Flight Center, Crofton, MD, USA. Esperanza Stancioff is Extension Educator, University of Maine Cooperative Extension \& Sea Grant, Waldoboro, ME, USA. Cassie Stymiest is Program Manager, Northeastern Regional Association of Coastal Ocean Observing Systems (NERACOOS), Portsmouth, NH, USA. Richard A. Wahle is Research Professor, University of Maine, School of Marine Sciences, Darling Marine Center, Walpole, ME, USA Jesica D. Waller is an MS candidate, University of Maine, School of Marine Sciences, Walpole, ME, USA, and Bigelow Laboratory for Ocean Sciences, East Boothbay, ME, USA. Nathan D. Rebuck is Postdoctoral Associate, NOAA NEFSC, Narragansett, RI, USA. Zhaohui A. Wang is Associate Scientist, Marine Chemistry \& Geochemistry Department, Woods Hole Oceanographic Institution (WHOI), Woods Hole, MA, USA. Todd L. Capson is Science and Policy Advisor, Sustainable Fisheries Partnership, Washington, DC, USA. J. Ruairidh Morrison is Executive Director, NERACOOS, Portsmouth, NH, USA. Sarah R. Cooley is Science Outreach Manager, Ocean Conservancy, Washington, DC, USA. Scott C. Doney is Department Chair, Marine Chemistry \& Geochemistry, WHOI, Woods Hole, MA, USA.

\section{ARTICLE CITATION}

Gledhill, D.K., M.M. White, J. Salisbury, H. Thomas, I. Mlsna, M. Liebman, B. Mook, J. Grear, A.C. Candelmo, R.C. Chambers, C.J. Gobler, C.W. Hunt, A.L. King, N.N. Price, S.R. Signorini, E. Stancioff, C. Stymiest, R.A. Wahle, J.D. Waller, N.D. Rebuck, Z.A. Wang, T.L. Capson, J.R. Morrison, S.R. Cooley, and S.C. Doney. 2015. Ocean and coastal acidification off New England and Nova Scotia. Oceanography 28(2):182-197, http://dx.doi.org/10.5670/oceanog.2015.41. 